\title{
EFFECTS OF FOREIGN EXCHANGE SUPPLY AND DEMAND DYNAMICS TO RUPIAH EXCHANGE RATE AND ECONOMIC PERFORMANCE
}

\author{
Sugeng \\ M. Noor Nugroho \\ Ibrahim \\ Yanfitri $^{1}$
}

\begin{abstract}
This study examines the influence of forex demand and supply interaction on Rupiah's exchange rate. Estimation results show that the movement of rupiah is influenced by the forex supply and demand, where the foreign players are dominating. Furthermore, the demand and supply of foreign exchange is asymmetric.
\end{abstract}

This paper also shows the impact of exchange rate movements on output is only in the short term with a more significant influence to the import, while the depreciation of Rupiah has a larger impact than its appreciation.

Keywords: Foreign exchange, inflation, exchange rate.

JEL Classification: E31, F31

1 Sugeng (sugeng@bi.go.id), M. Noor Nugroho (nugroho@bi.go.id), Ibrahim (ibrahim@bi.go.id) and Yanfitri (yanfitri@bi.go.id) are economist on BRE - DKM Bank Indonesia. The authors thank to Made Sukada, Dr. Iskandar Simorangkir and other researchers for their valuable contribution on this paper. 


\section{INTRODUCTION}

Exchange rate is an important economic indicator that has a strategic role in an economy. Exchange rate movement widely influence various aspects of economy, including inflation, import-export performance which in turn affects the output of economy. In addition, the exchange rate movement are like a double-edged sword, for example, in the event of depreciation, exporters are benefited since the prices of Indonesian exported products relatively turn out to be cheaper. Conversely, depreciation of rupiah may be detrimental for importers and foreign debt debtors within increased cost of imports and foreign debt payment burdens (equivalent in domestic currency). Depreciation also increases inflationary pressures in which if inflation increases significantly, it will have negative impacts throughout the economy. The impact will ultimately depend on the ratio of positive and negative effects of rupiah depreciation. In the case of rupiah appreciation, it will apply vice versa.

Indonesia as an open economy with floating exchange rate system also faces the above dilemma, especially when rupiah moves very volatile as happened in the last quarter of 2008 after the global financial crisis. Such case contributes negative impacts impact to the domestic financial market and the overall economy.

Taking into account that the exchange rate movement are quite volatile and the negative impacts are quite extensive to the economy, efforts to maintain exchange rate stability are not easy challenges for the Bank of Indonesia in the midst of a very open economy within a free forex system and a floating exchange rate regime. Rupiah stability turns out to be increasingly crucial in association with the inflation target achievement and concerning that the impacts of exchange rate to inflation and inflation expectations are quite high (Kurniati, 2007, Kurniati et al, 2008).

In the efforts to maintain the exchange rate stability, recognizing the factors affecting the movements is required. Many studies have been made to develop exchange rate models that may explain the influencing factors and may measure the significance and magnitude of each factor's effect. In the Bank of Indonesia, several studies on rupiah exchange rate by using macroeconomic fundamentals variable have also been carried out, such as Behavioural Equilibrium Exchange Rate (BEER) model that shows the movements of rupiah real exchange rate is significantly influenced by risk factors and several macroeconomic variables, namely interest rate differential, terms of trade, productivity and net foreign assets. The study shows that the rupiah movements are more influenced by the risk factors than the macroeconomic variables. Besides for the evaluation purposes or assessment on rupiah movements, the BEER model is also used to forecast the rupiah exchange rate. Other models that are also developed 
- as a comparison to the BEER model - are the Fundamental Equilibrium Exchange Rate (FEER) model and the Effective Real Exchange Rate model, which also utilize a macroeconomic approach.

In practical research, the exchange rate modelling is one of very difficult topics to apply. Consequently, it is hard to find the model that is satisfactorily able to explain the phenomena of exchange rate movement, especially to forecast the exchange rate. A model may appropriately explain exchange rate developments in a certain country and within a certain period, but at other time, the same model may not function similarly. To handle weaknesses, many economists and practitioners (as well as the central banks) endeavour to construct several alternative models so that such models can complement one another to explain exchange rate movement accurately.

By paying attention to the above issues, this study aims to provide an alternative exchange rate model (as well as with an alternative approach) in order to explain exchange rate movement better. The approach used is the forex supply and demand approach in the domestic forex market. Theoretically, the interaction between forex supply and demand - as a commodity traded in the forex market - will establish a price, which in this case is the rupiah exchange rate (rupiah against the US dollar). Referring to the theory, the exchange rate model to be generated by this study may explain the effect of forex supply and demand dynamics for rupiah exchange rate movement. In addition to measuring the impact on exchange rates, it will further measure the effects to the economic price and output.

In addition to further enrich an understanding on the supply and demand dynamics in the domestic forex marketing in order to increase the added value of resulted exchange rate model, this study also analyzes the structure of forex market that includes market participants, their characteristics and forex transactions applied, as well as their impact on the rupiah exchange value development.

In implementing this study, there are several things that have very wide or even specific definitions. Forex market shall be interpreted as any activity related to exchange or purchasing and selling of one currency to the other currency. Therefore, any forex transaction that occurs between one person and the other without considering where the transaction takes place, such as any forex transaction in any money changer, any bank, and forex transaction between banks, may be interpreted as a forex market. In this study the definition of forex market is restricted only on any forex transaction occurring in any domestic banking sector (banks functioned as the forex market), and reported by the banks to the Bank of Indonesia through the Commercial Bank Daily Report (LHBU) which includes (i) individual, (ii) corporation, (iii) domestic banks and (iv) foreign parties. 
A bank serves as a forex market, due to its role to serve as an intermediary to bring together supply and demand. A bank may be equated as a forex market since it tends to be neutral, although a bank may also carry out transactions for its own interests and take long or short forex position. However, the bank's position is relatively limited (near-neutral) because:

- Bank risk management will lead the bank to the neutral position to avoid exchange rate risk, and

- In case the bank takes a risk by taking a long / short forex position, the bank is limited by the terms of the net open position.

Forex supply and demand in this study shall refer to any effective supply and demand since it has been realized in the form of forex transactions. Forex supply and demand are distinguished from the bank's point of view - as the forex market - based on the flow of forex arising from forex transactions conducted by the bank.

Forex supply is specified as forex flows into the market, so that the representing forex transactions are forex purchase transactions (rupiah sales) performed by the bank in which the bank receives forex from the counterpart, whereas to the counterpart, the bank hands over rupiah to the counterpart within an equivalent amount.

Conversely, demand is defined as forex flows out of the bank which is represented by forex sale transactions by the bank. The accumulation of all purchase and sale forex transactions by the bank will show the bank's position as a net purchase (purchase transaction is larger than sale transaction) or the net sale which may also be equated with excess supply or excess demand.

The second section of this paper reviews the theory underlying this study, while the third section discusses the data and methodology used. Furthermore, the fourth section reviews the results of the estimate and analysis, while conclusions and suggestions will take part as the closing section.

\section{THEORY}

\section{II.1. Theory of Demand and Supply}

In the market, there are two main forces that interact with each other, namely supply and demand, in order to form an equilibrium reflected in the price and quantity levels where supply and demand curves meet. Law of demand connects a various combination points between the amount of goods (or services) and the price levels offered. The higher the price, the higher the quantity will be supplied - or vice versa when the price falls - within a-ceteris paribus assumption, so that there is a positive relationship between the price and the supply. 
In the context of forex market, the commodity traded is the forex, whereas the price is the exchange rate. For the US dollar market in Indonesia, the price of US dollar is the rupiah exchange rate per US dollar, for example with a quotation of IDR 9,000/USD; in case the quotation increases, it means the price of USD1 purchased with the rupiah currency turns out to be more expensive. This condition is called rupiah depreciation (the rupiah value decreases) or US dollar appreciation. Conversely, if the quotation declines, then rupiah appreciation occurs (US dollars depreciation).

As in other markets, excess demand against the US dollar causes rupiah depreciation, and conversely, excess supply results in US dollar depreciation (rupiah appreciation). An exchange model within a microstructure approach uses the same principle, namely to measure the effect of 'excess demand"- using the order flow data - to the exchange rate movement.

Order flow refers to an order or request to conduct forex transactions from one party to a forex dealer, which in this case serves as the market maker or the market. By serving as a market maker, the dealer may receive any sale order and purchase order. In the concept of order flows, sale and purchase orders of forex are distinguished by giving a positive mark (+) for forex purchase orders (the dealer sells the forex to the buyer) and a negative mark (-) for the forex sale orders. The order flow accumulation is empirically proven by Evan and Lyons (2005) that affects the exchange rate.

The main explanation of explanatory power is an order containing a lot of information potentially affects the exchange rate. Before ordering, the buyer has to obtain information, including information concerning macroeconomic fundamentals (Rime, 2007) from various sources and then process (analyze) such information that eventually create future expectation of exchange rate. Based on this expectation, a buyer delivers a forex transaction order, which aims to gain profit. Since the orders come from various circles that have great variety of information, the order flow accumulation is synthesized from a variety of information, so it is able to explain the direction of exchange rate movement.

The signing to distinguish the direction of forex transactions makes the order flow is often referred to as a variant of 'excess demand'. Based on this fact, relationship between the order flow and the exchange rate may be found, namely higher order flow (excess demand) will increasingly put depreciative pressures to the exchange rates. The general form of the order flow equation is as follows:

$$
\Delta \mathrm{P}_{\mathrm{t}}=\mathrm{f}(X, \mathrm{I}, \mathrm{Z})+\varepsilon_{\mathrm{t}}
$$

Where $\Delta \mathrm{P}_{\mathrm{t}}$ is the change of exchange rate, $\mathrm{X}$ is the order flow, $\mathrm{I}$ is the forex reserves held by a market maker, and $\mathrm{Z}$ is the other micro indicators. 
A study on a supply and demand approach has also been taken in the Bank of Indonesia by Husman (2005). This study uses a composite (hybrid) model that combines forex supply and demand with economic fundamental variables to explain exchange rate movement. The equation of such intended composite exchange rate model is as follows:

$\mathrm{s}_{\mathrm{t}}=\alpha_{0}+\left(\mathrm{p}_{\mathrm{t}}-\mathrm{p}^{*}{ }_{\mathrm{t}}\right)+\alpha_{1}\left(\mathrm{i}_{\mathrm{t}}-\mathrm{i}^{*}{ }_{\mathrm{t}}\right)+\alpha_{2} \mathrm{sdv}_{\mathrm{t}}+\alpha_{3} \mathrm{tot}_{\mathrm{t}}+\alpha_{4} \mathrm{p}_{\mathrm{oil}}+\mathrm{u}_{\mathrm{t}}$

where $s_{t}$ is the exchange rate, $p_{t}-p^{*}{ }_{t}$ is the price differential, $i_{t}-i^{*}{ }_{t}$ is the interest rate differential, $s d v_{t}$ is the ratio of foreign forex supply and demand, tot $t_{t}$ is the term of trade and $p_{\text {oil }}$ is the world oil price. The study results show that the supply and demand variables significantly influence the movement of exchange rate.

\section{II.2. Exchange Rate, Inflation and Monetary Policy Transmission Pass-Through}

Exchange rate movement as indicated on the background has broadly influenced the economy, including the price. Exchange rate in influencing the price may be through various pass-through of transmission:

- Direct pass-through

- Indirect pass-through

- Inflation expectation

In the direct pass-through, changes in the exchange rate may affect the import prices of goods (in domestic currency), which is reflected in the import price index. The main problem related to the issue of pass-through effect is the effect of exchange rate depreciation which directly increases the import costs to be borne by importers that causes the increase of import price. Furthermore, importers or retailers who sell imported goods to customers have some alternatives to bear the cost increase on their own or impose the charge of cost increase to their customers in the form of raising the customer price. In case importers would like to maintain their profit, the rupiah depreciation expense will be charged to the customers so that the customer prices increase. However, if importers are willing to bear it - by reason of maintaining their market share - hence the rupiah depreciation will give minimum impacts to customer prices.

Impact of changes in exchange rates through indirect pass-through is through shifting the marketing orientation of domestic market into international markets. Depreciation makes the price of exported goods cheaper, which subsequently encourages the exports. For domestic manufacturers, it is a potential for greater profits that it will be more profitable if their produced goods are sold to overseas markets than to domestic markets. Due to changes in the market 
investment, the prices of these goods in the country become more expensive (inflation). Meanwhile, expectation point enlightens that the exchange rate depreciation will cause future prices that tend to increase. This expectation is realized by manufacturers and retailers to make anticipatory measures on price adjustment (raising the prices). As a result, inflation tends to rise.

In this study, the effects of exchange rate changes to prices (inflation) through a direct pass-through will be estimated. Therefore, the estimate will be divided into two stages: the first stage or the first round effect is known as the effects of changes in exchange rates to import prices, and the second round effect is the influence of import prices to customer prices. An equation model used is in reference to Kurniati (2007) with the following equation:

$P_{m}=\mathrm{f}\left(e_{t}, P_{\text {int } t}, P_{\text {oil }}, Y\right)$; first round effect

$P=\mathrm{f}\left(P_{m}, P_{\text {oil }}, Y_{t}\right)$; second round effect

Where $P$ is the $\mathrm{CPI}, P_{m}$ is import price, $e$ is the exchange rate, $P_{\text {int }}$ is the price indicator of trading partner nations, $P_{\text {oil }}$ is the world oil price, and $Y$ is GDP.

\section{II.3. Determinants of Export and Import Performance}

Exports and imports are the implementation of an open economic system in which a country performs trading activities with other countries. The dynamics of exports and imports will also affect the balance of payments and the overall economic outputs. The exchange rate is closely linked both to exports and imports of which exchange rate movement affect the competitiveness of export products (in terms of relative prices). Depreciation of an exchange rate of one country against another country's currency makes the country's competitiveness of export products increases, so that exports rise as well. At the same time, imports become more expensive for such country, which tends to decline. Combination of increased exports and decreased imports improves the condition of balance of payments, and will further increase revenues. An opposite effect occurs when the exchange rate is appreciated, namely the performance of the balance of payments and the national revenue becomes worse.

In addition to the exchange rate, exports and imports are also influenced by the terms of trade, export goods supply side and demand side (the exports and the imports). Improved terms of trade will contribute positive impacts to the exports, but adversely influence the imports. For exporting countries, the availability of goods supplied may be reflected in their production, while the goods import demand is reflected by their revenue. Thus, export and import equations may be expressed as follows: 
$X=\mathrm{f}\left(e, T O T, I P^{*}\right)$

$M=\mathrm{f}(e, T O T, Y)$

Where

$X$ is the export, $M$ is the import, $e$ is the exchange rate, $T O T$ is the terms of trade, $I P^{*}$ is the industrial production index, the trade partner countries representing revenues.

Furthermore, exports and imports affect the national revenue as indicated in the identity equation of domestic output in an open economic system:

$Y=C+I+G+(X-M)$

Where $Y$ is the GDP, $C$ is the consumption, $I$ is the investment, $G$ is the government spending, and $X-M$ is the net exports (exports - imports).

\section{METHODOLOGY}

The method of analysis is divided into two, the first is a descriptive analysis of domestic banking forex market aims to determine the forex market microstructure; including conducting studies on the market players and its characteristics, demand, supply and exchange rate developments, and transaction patterns. The second part is an analysis applying the simultaneous equation econometric estimate technique. Based on the model developed, shock simulation occurring either on forex demand or supply is conducted. The simulation is also conducted to refine the analysis and to test whether or not the model is robust.

\section{III.1. Empirical Model}

The framework of empirical model developed in this study is a simultaneous equation system. The simultaneous equation model to be estimated consists of five behavioural equations (behavioural equation) and one identity equation such as follows:

$$
\begin{aligned}
& e_{t}=\mathrm{b}_{10}+\mathrm{b}_{11} S D_{-} L N_{\mathrm{t}}+\mathrm{b}_{12} S D_{-} L N_{\mathrm{t}-1}+\mathrm{b}_{13} S D_{-} D N_{t}+\mathrm{b}_{14} S D_{-} D N_{t-1}+\mathrm{b}_{15} R I S K_{t}+\mathrm{b}_{16} N E E R_{t}+u_{l t} \\
& X_{\mathrm{t}}=\mathrm{b}_{20}+\mathrm{b}_{21} e_{t}+\mathrm{b}_{22} T O T_{t}+\mathrm{b}_{23} I P^{*}+u_{2 t} \\
& M_{\mathrm{t}}=\mathrm{b}_{30}+\mathrm{b}_{31} \mathrm{e}_{\mathrm{t}}+\mathrm{b}_{32} \mathrm{TOT}_{\mathrm{t}}+\mathrm{b}_{33} \mathrm{Y}_{\mathrm{t}}+u_{3 t} \\
& Y_{t}=C_{t}+I_{t}+G_{t}+X_{t}-M_{t} \\
& P m_{\mathrm{t}}=\mathrm{b}_{40}+\mathrm{b}_{41} e_{t}+\mathrm{b}_{42} P_{t}^{*}+\mathrm{b}_{43} P_{\text {oilt }}+\mathrm{b}_{44} Y_{t}+u_{4 t} \\
& P_{t}=\mathrm{b}_{50}+\mathrm{b}_{51} P m_{t}+\mathrm{b}_{52} P_{\text {oilt }}+\mathrm{b}_{53} Y_{t}+u_{5 t}
\end{aligned}
$$


where $e$ is the nominal exchange rate, $S D \_D N$ and $S D \_L N$ is the net demand and forex supply from foreign and domestic parties, RISK is the risk factor, NEER is the composite exchange rate of a few global currencies, $X$ is the export, TOT is the term of trade, $I P^{*}$ is the industrial production index of trading partner countries, $M$ is the import, $Y$ is the domestic revenue / output, $C$ is the consumption, $I$ is the investment, $G$ is the government spending, $P m$ is the import price, $P^{*}$ is the foreign price, $P_{\text {oil }}$ is the world oil price, and $P$ is the customer price.

Concerning that the above equations are one-way effect ( $e_{t}$ affects $P m_{t^{\prime}} P_{t}, X_{t}$ and $M_{t}$, and subsequently $X_{t}$ and $M_{t}$ affects $\left.Y_{t}\right)$ ) and there is no looping or reverse effect or mutual effect, then the estimate of such equations will be done partially. Furthermore, the results of the said partial estimate will be combined in one simultaneous equation system. Having such method, it is expected that such estimate may be efficient so that a consistent equation may eventually produced.

The first equation is an equation of exchange rate that is consistent with an order flow approach developed by Lyons (2001) such as follows:

$\Delta \mathrm{P}_{\mathrm{t}}=\mathrm{b}_{0}+\mathrm{b}_{1} \mathrm{X}_{\mathrm{t}}+\mathrm{b}_{2} \mathrm{I}_{\mathrm{t}}+\mathrm{b}_{3} \mathrm{Z}_{\mathrm{t}}+\varepsilon_{\mathrm{t}}$

where $\Delta P_{t}$ is the change of exchange rate (IDR / USD), $X_{t}$ is the order flow, $I_{t}$ is the forex reserves held by a market maker, and $Z_{t}$ is the other indicator. Additional indicators are risk factors and global exchange rates.

Variable $X_{t}$ - net forex purchase by the bank - is expected to negatively affect the exchange rate; if the net purchase or excess supply (see the description below) increases, the rupiah rate then will be appreciated (quotation of IDR / USD is down). Conversely, the decline in the net purchase results in rupiah depreciation. The $I_{t}$ forex reserves are also expected to negatively affect the exchange rate. High forex reserves of a certain bank will encourage such related bank to release the forex.

In this study, the order flow data is replaced by spot transactions occurring in a domestic banking sector (banks $\sim$ dealers in the concept of microstructure market). Therefore, some designations of terms are required to be clarified:

- A bank is equated with a dealer in terms of its role as a forex market associated with several crucial similarities, namely:

o The bank may enter into two-way transactions (sale and purchase) so that it may bring together demand and forex supply, and distribute such excess supply/demand to the entire market.

o Neutrality; the bank tends to be neutral - excessive supply/demand of forex is forwarded to the other market participants - since the bank tends to be risk averse and - in case- 
the bank take (long / short of forex) position - the bank's position is restricted by the prudential regulation of Net Open Position.

- Forex supply is specified as forex transactions conducted by a bank within a consequence of forex flows into the bank, namely forex purchase transactions (forex sale from the bank counterpart).

- Forex demand refers to forex transactions conducted by a bank within a consequence of forex flows out of the bank, namely forex sale transactions (forex purchase from the bank counterpart side).

- When a purchase transaction (supply) is provided with a positive mark, whereas the sale transaction (demand) is provided with a negative mark, then the accumulation of such transactions are net purchase - when it is positive, it means that the bank has an excess supply transaction with its counterpart, or vice versa, when it is negative, it means that the bank experiences an excess demand.

Equation III.5 and equation III.6 are import price equations and customer price equations. Estimate of exchange rate effect to the price (exchange rate pass-through) refers to the existing study prepared by Kurniati (2007). In such study, the effects of exchange rate change to the price are estimated through the direct pass-through. Before affecting the customer price, the effects will be transmitted through the import price. Increased import cost due to price changes will encourage importers to sell their imported goods to the domestic markets with higher prices in order to maintain their profits.

Besides because of changes in exchange rates, import prices are also directly influenced by price developments in the country of origin where the imported goods, oil prices, and domestic revenues come from. Changes in the price of imported goods in their home country directly affect the import costs should be borne by the importers, so that the price increase of trading partner countries has positive effect to the import price. Oil price may affect the imported goods price - although such price has no direct relationship with the oil - through the increase of production cost since most of the entire production process requires such energy source (the oil). Therefore, the increase of oil prices will increase the import price as well. Oil price also leads to the increase of domestic production cost, which in turn shall raise the price of goods in general. Meanwhile, domestic revenues also strongly affect the import demand and the domestic product demand, which eventually may increase the import and customer prices. Referring to this description, Equation III. 5 shows the first round effect, while Equation III. 6 shows the second round effect.

Equation III.2 in the simultaneous model above shows the export equation, whereas Equation III.3 represents the import equation. Exchange rate directly affects the export and 
import performances of an economy through the effects of price competitiveness. Depreciation makes domestic goods price is relatively cheaper, so it provides an incentive for foreign customers to buy more, which means that the export shall increase. However, the exchange rate is not the only factor that affects the export. Exports are determined by interactions between the demand side which are generally represented by the revenues of trading partner countries, which in this case - since the estimate uses monthly data - are represented by US Industrial Production Index.

On the other hand, import of such countries obtains impacts contrary with the export as described above. If depreciation is profitable for the export, the import is depressed since the price of imported goods relatively becomes more expensive. As a result, the import decreases by the domestic currency depreciation. However, the impact ultimately depends on the strength of domestic demand for imported goods that is represented by domestic revenues. The higher domestic revenue, the higher import demand is. The other factor that affects the import, as well as the export, is the terms of trade. However, the effects greatly depend on the export and import conditions.

Effects of changes in exchange rates - in this case the appreciation - to the increased exports and decreased imports will in turn improve the trade balance, balance of payment, and furthermore the output - when the Marshall-Lerner condition is met.

To close the equation system, an identity equation namely the national revenue is utilized: $Y=C+I+G+(X-M)$. Visually, simultaneous connections between all variables involved are illustrated in the following scheme:

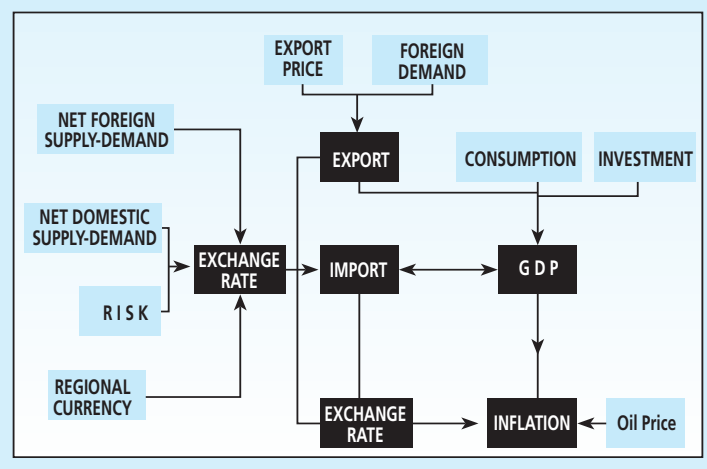

Scheme III.1

Simultaneous Equation Model 


\section{III.2. Initial Identification}

Endogeneity test and the order and rank condition of identification (or also known as the order condition) is firstly conducted to identify a simultaneous model. Granger causality test results indicate that there is an endogeneity in the equation (See Table 4.7). The order condition test is conducted by following a procedure of Gujarati (1995), namely, $K-k \geq m-1$, where $K$ is the number of predetermined variables in the model, $\mathrm{k}$ is the number of predetermined variables in certain equations, $\mathrm{m}$ is the number of endogenous variables in certain equations. When ( $\mathrm{K}$ $k) s=(m-1)$, it may be said that the equation is exactly identified or properly identified, and if $(K-k)>(m-1)$, it may be said that the equation is over identified. Conversely, when $(K-k)<$ $(m-1)$, it is concluded that the equation is under identified and cannot be estimated.

In the system of simultaneous equation above there are 11 predetermined variables and six endogenous variables. Following the identification procedure of order condition, the overall equation is over-identified.

By using other formulations - namely $(\mathrm{K}-\mathrm{M})>(\mathrm{G}-1)$, where $\mathrm{K}$ is the number of variables used in the system (17), $M$ is the number of variables specified in certain equation (6), and $G$ is the total of equation (6), thus (17-6)> (6-1) - the same conclusion is also obtained, namely overidentified. Since the estimate result of order condition shows that partial equation in the system of simultaneous equation is over identified, the estimate will use Two Stage Least Square method. The estimate result for each of these equations is discussed as the following below.

\begin{tabular}{|c|c|c|c|c|c|c|c|c|c|c|c|c|c|c|}
\hline & & & & Sun & imar & for the $\mathrm{E}$ & $\begin{array}{l}\text { le II } \\
\text { Idog }\end{array}$ & 1 & t Resu & & & & & \\
\hline & ER & $\begin{array}{l}\text { Foriegn } \\
\text { SD }\end{array}$ & $\begin{array}{l}\text { Domestic } \\
\text { SD }\end{array}$ & RSK & NEER & INTERNATIONALP & Oll.P & DOMESTICP & IMPORTP & $p$ & EXPORT & TOT & INTERNATIONAL IP & IMPORT \\
\hline ER & & & Y & Y & & & & & y & & & & & y \\
\hline Foreign SD & & & & & y & & & y & y & & y & & Y & y \\
\hline Domestic SD & & & & & y & & & y & y & y & y & Y & & \\
\hline RISK & & y & y & & & y & & y & y & & y & y & y & y \\
\hline NEER & y & y & y & & & y & & & y & & & & y & y \\
\hline INTERNATIONAL P & & & y & & y & & & & y & & y & y & & y \\
\hline OILP & y & y & y & & y & y & & y & y & & y & y & & y \\
\hline DOMESTIC P & & y & & & & & & & & & y & $\bar{y}$ & y & \\
\hline IMPORT P & y & y & & & y & & & y & & & & & & y \\
\hline$P$ & & & & & y & & & Y & y & & & y & & y \\
\hline EXPORT & & y & & & & y & & y & & & & y & y & y \\
\hline $\begin{array}{l}\text { TOT } \\
\text { INTERNATIONAL IP }\end{array}$ & & y & y & & & y & & $\begin{array}{l}\text { y } \\
\text { y }\end{array}$ & y & & & Y & & y \\
\hline IMPORT & & & & & y & & & y & $(Y$ & & & & & \\
\hline
\end{tabular}




\section{III.3. Data}

By considering various models of the above equations to be estimated, the data to be used covers:

- Rupiah exchange rate against US dollar (IDR), source: Bloomberg,

- Supply and demand transactions of forex, source: LHBU,

- Foreign assets ratio against foreign liability of bank (FA / FL), source: DSM,

- EMBIG index as the risk indicator, source: JP Morgan-Chase,

- Currency exchange rates of some trading partners processed to be a composite index of nominal exchange rate (NEER), source: Bloomberg

- The customer price index (CPI), source: DSM,

- Import prices index (Pm), source: DSM,

- Inflation of trading partner countries, source: CEIC

- World oil price, source: Bloomberg,

- GDP, source: BPS

- Terms of trade, source: DSM,

- US Industrial Production Index, source: CEIC.

Estimate of the model will use monthly data during the observation periods from January 2004 to December 2008. Particularly, a forex market practice analysis will use daily data of forex transactions within observation periods from January 2004 to April 2009.

\section{ESTIMATE AND ANALYSIS RESULTS}

\section{IV.1. Forex Market Review}

In accordance with the microstructure analysis of forex market there are some interesting findings obtained from the development, characteristics and behaviour of the forex market and market participants. Such intended findings include: imbalanced forex market developments; foreign players, although their transaction is not the largest but able to influence the other market participants; a "hot money"indication of foreign participant fund coming into the forex market (capital inflows); asymmetric impact of inflows and outflows against the exchange rate movement; and the transaction patterns between the market participants. These findings will be described further hereunder.

\section{IV.1.1. Forex Market Developments}

Forex market has been developing well enough and able to support the economic activities, especially those related to international trade and cross-border investment. Forex market 
transaction volume averagely increases about 25.9\% (yoy, in the periods of 2004 to 2008), whereas the export and the import grows averagely $11.1 \%$ and $11.5 \%$ (Figure III.1). However, rapid growth only occurs at a spot transaction segment where the highest monthly transaction volume reaches USD 72 billion (September 2008), or averagely amounting to USD 3.3 billion per day, before sharply decreases during the explosion of global financial crisis in October 2008 (Figure III.2).

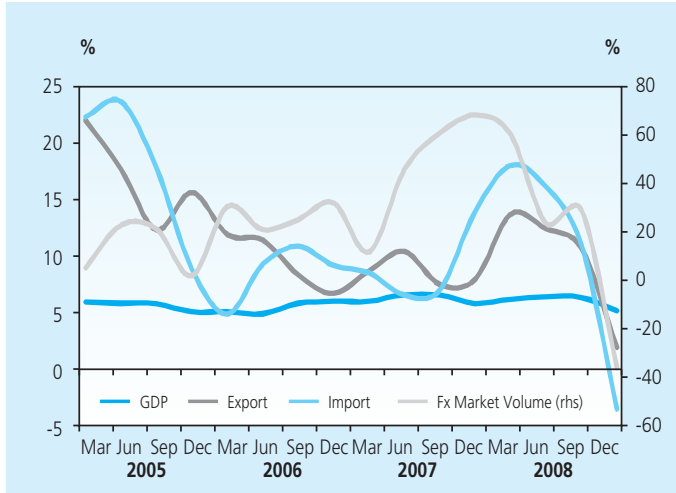

Figure III.1.

Growth of GDP, Export, Import and Forex Market Volume

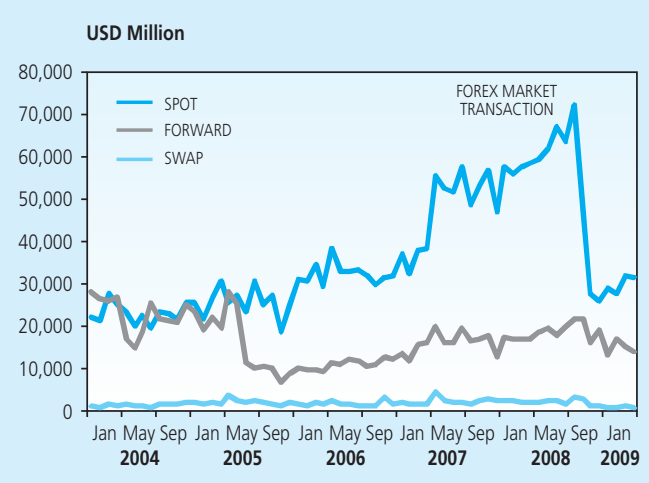

Figure III.2.

Development of Forex Transactions

The development of spot transactions, especially in 2008, may also be seen from the value and frequency increase (number of transactions) of spot transactions. Value and frequency of each spot transaction rises $10.3 \%$ and $80.6 \%$ (compared to 2007) to be USD 506.6 billion and 3.4 million times of transactions. Meanwhile, although the spot transaction value tends to decrease at the end of 2008 , for entire 2008 , the average daily transaction increases $12.2 \%$ to be USD 2.1 billion.

Meanwhile, swap and forward transactions are relatively stagnant (Figure III.2). Swap transaction volume drops dramatically since the enactment of swap transaction restriction without relying on the economic activities in mid 2005. The third market share of such segment contains about $77 \%$ of spot transactions, $19 \%$ of currency swap transactions, and $4 \%$ of forward transactions.

Less balanced development also occurs in forex transactions based on the currency traded. Trade transactions of US dollars (USD) against rupiah dominate the market within an average market share reaching 76\% (Figure III.3). Trade of other strong currencies, such as Euro and Japanese Yen, only have a share of $1 \%$ respectively. Such composition is in line with Indonesia's 


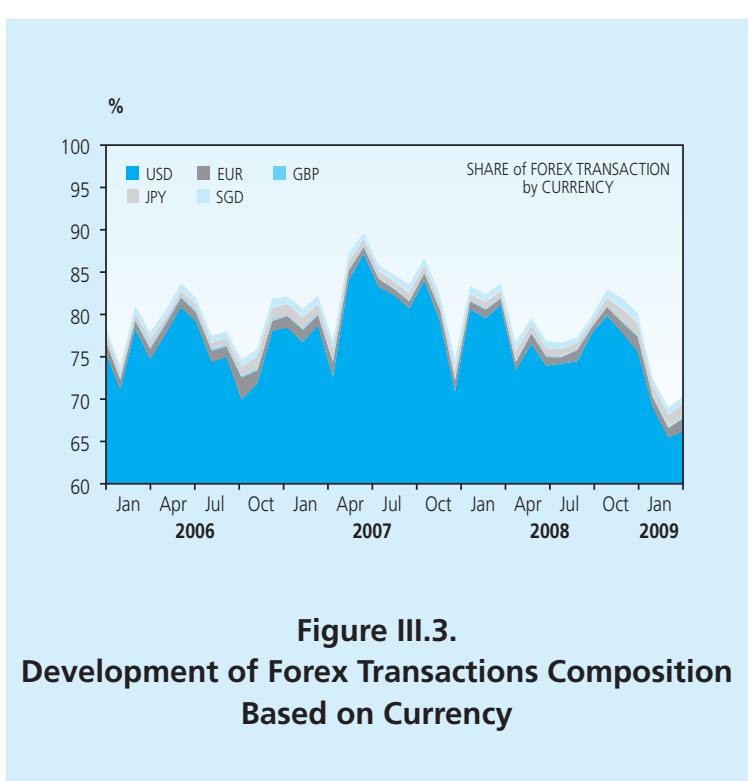

\begin{tabular}{|c|c|}
\hline $\begin{array}{c}\text { Table III.2 Cor } \\
\text { Export-Impor } \\
\text { Based on }\end{array}$ & $\begin{array}{l}\text { osition of } \\
\text { ansaction } \\
\text { rrency }\end{array}$ \\
\hline Information & $\begin{array}{c}\text { Type of Currency } \\
\text { Share (\%) }\end{array}$ \\
\hline $\begin{array}{l}\text { Non-oil/gas exports } \\
\text { USD - US\$ } \\
\text { SGD - SINGAPORE \$ } \\
\text { EUR - EURO } \\
\text { JPY - JAPANESE YEN } \\
\text { otherS }\end{array}$ & $\begin{array}{r}93.3 \\
2.0 \\
1.7 \\
1.6 \\
1.4\end{array}$ \\
\hline $\begin{array}{l}\text { Non-oil/gas imports } \\
\text { USD - US\$ } \\
\text { SGD - SINGAPORE \$ } \\
\text { JPY - JAPANESE YEN } \\
\text { EUR - EURO } \\
\text { otherS }\end{array}$ & $\begin{array}{r}83.7 \\
4.8 \\
4.6 \\
4.1 \\
2.9\end{array}$ \\
\hline
\end{tabular}

international trade that mostly (93\% of the total exports and $83.7 \%$ of the total imports) uses US dollars for payment (Table III.2). In addition, the composition of the Indonesian Foreign debt is also dominated by foreign currency in US dollars. Private foreign debt as of February 2009 in the form of US dollar reaches $88 \%$ or equivalent to USD 53 billion. Meanwhile, the second largest proportion is about $9 \%$ in Yen.

\section{IV.1.2. Market Participants/Players}

Forex market participants may basically be separated into two major groups, namely (1) market makers who act as the market and (2) market participants who act as the counterpart to conduct forex transactions with the market makers. Market makers, which in the scope of this study are banks classified as State Banks, Private Forex Banks, Private Non-Forex Banks, Regional Development Banks, Joint Banks and Foreign Banks. Banks function as the market since they tend to be neutral to the long/short position of forex. Such bank neutrality is because the risk management of banks tends to be risk averse, prudential regulation of net open position (NOP) that restricts the forex position of banks, and banks receive purchase/supply orders of foreign currency so it allows them to distribute demand and supply to the entire market. Meanwhile, the counterpart of banks may be classified into corporation, individual customer, and foreign players.

Market participants considered significant or called as significant players are market participants having a special role in the forex market. For the market makers, foreign banks are 
considered as significant players since they have the largest network of transactions, including becoming a gateway for foreign players to enter into domestic financial markets. Such large network allows foreign banks to make the market share to be over $41 \%$ of the total transactions (Figure III.4). Development of Foreign Bank market share is relatively stable of over $40 \%$ since 2003. Private Forex Bank market share tends to decline and is replaced by State Banks and Joint Banks whose market shares increase (Figure III.5).

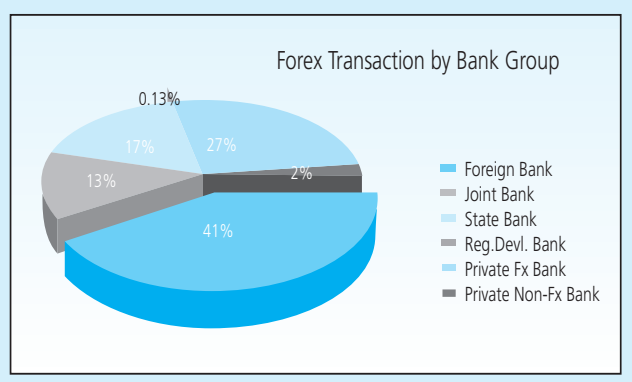

Figure III.4. Bank Group's Market Share

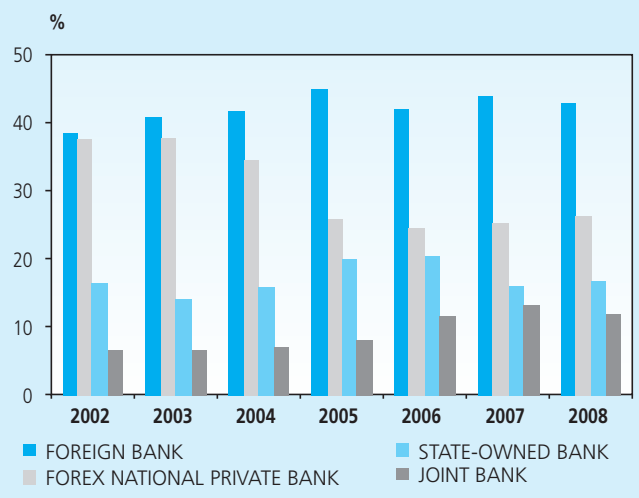

Figure III.5. Market Share Growth

Although foreign banks have the highest market share, the highest market share of individual banks is obtained by Bank Mandiri (limited liability company bank) whose market share reaches $8.7 \%$ of the total forex transactions in 2008. Foreign banks having significant market share consist of Standard Chartered Bank, Citibank, HSBC, ABN Amro Bank, Deutsche Bank and JP Morgan Chase.

For counterpart bank group, foreign (foreign) player group is a significant player even though its market share (25\%) is lower than the market shares of interbank transactions (35\%) and corporation (28\%) groups (Figure III.6). Predicate as significant players is more because the quite large transactions of foreign players whose transaction value during the observation period reaches USD 1.6 million in average (compared to domestic players, which is only USD 242 thousand per transaction). This allows foreign players able to influence exchange rates and to formulate exchange rate expectation which in turn may influence the forex transactions of other market participants. Forex transactions of foreign players are concentrated within foreign banks as the main partners have the market share that reaches about $80 \%$ of the total foreign player transactions (Figure III.7). 


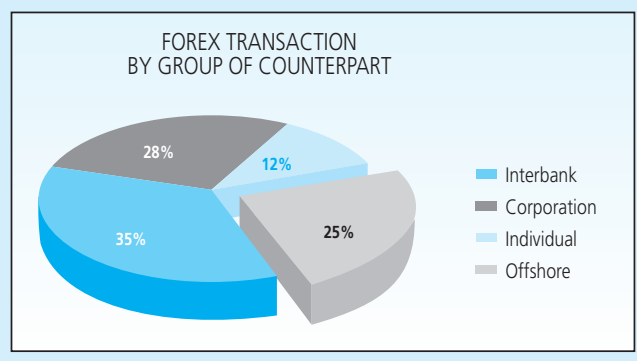

Figure III.6.

Counterpart Bank Market Share

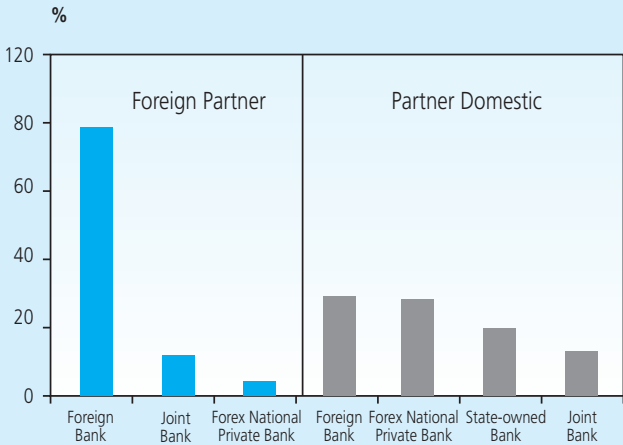

Figure III.7.

Bank Transaction Share by Partner (average of 2006-2008)

One thing should be concerned from the structure of forex market participants is the dominance of few market participants. In market makers group, forex market is dominated only by some banks, where 10 large banks control around $62 \%$ of the total transactions of forex market. In case the list of largest banks is extended to be 20 largest banks, the market share raises to be $87 \%$ of the total forex transactions. Similar to the market makers group, the forex transactions of foreign player group are also dominated by some players only, where 10 to 20 foreign players with the largest forex transactions have a market share of $56 \%$ and $73 \%$ of the total forex transactions made by foreign players. In the corporation group, the value is relatively more homogeneous, in which 10 corporations having the largest forex transactions own a portion of $29 \%$, whereas the 20 largest corporations has a market share of approximately $34 \%$. However, in this group, in fact, there is a very dominant market player, namely Pertamina.

\section{IV.1.3. Characteristics of the Market Participants}

Forex market participants have different behaviours and roles. One factor to distinguish the characteristics of market participants is the motivation to conduct forex transactions. Most market participants do so in order to support or related to their business activities, for example, exporters regularly sell forex generated from the proceeds of their export activities, importers buy forex to pay their imported goods, foreign debt debtors buy forex to pay off their debts, foreign investment companies sell forex coming from the operational funds of their parent companies abroad, and so on. Transactions whose economic motivations such like this are often called as genuine demand or genuine supply. The implication of such genuine transaction motivation to the behaviour of market participants tends persistently to be one-way transactions 
(sell only or buy only), thus the difference between forex selling and buying transactions (net of transactions in absolute terms) conducted closes to the total transactions (sales + purchases).

On the other hand, some market participants conduct forex transactions to obtain profits from two-way transactions - sale and purchase - conducted in a short period, even in one day (intraday). Such kind of transactions is often called as trading and full of speculative nuance. Its implication to forex transactions is: the total transaction is quite high - the sale and purchase frequency is relatively high - but its position finally tends to be square position (buy sell). Since it is not based on certain underlying permanent economic activity, forex transactions of foreign players become very flexible - may switch the roles quickly from net supply to net demand, or vice versa - in order to maximize profits.

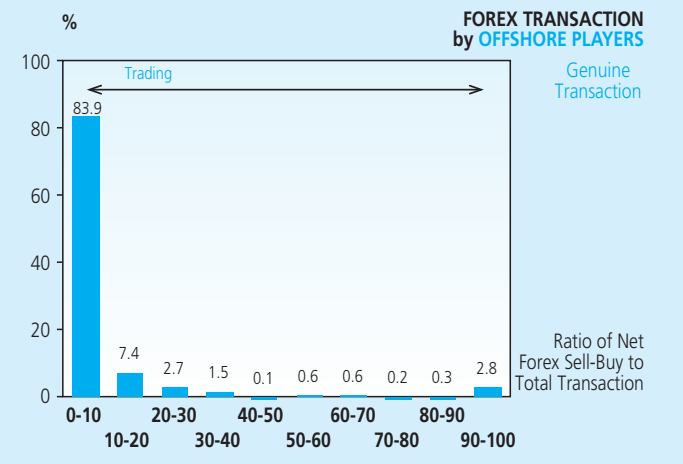

Figure III.8.

Trading Indications by Foreign Players

Referring to the distinction on the characters of market participants, behaviour of foreign players is fairly the same, namely forex transactions that lead to trading. This is indicated by the ratio between net purchases to the total transactions that is close to zero, even the majority (84\%) of the total forex transactions of foreign players are in the range of lowest ratio, namely less than $10 \%$ (Figure III.8). Such Similar behaviour of foreign players is because almost all foreign players who actively conduct forex transactions are international financial institutions or institutional investors whose primary goal is to invest in domestic financial markets.

Corporation group is divided into two within almost balanced proportion, 53\% of corporation tends to perform trading and $47 \%$ are likely to conduct forex transactions due to genuine demand/supply (Figure III.9). Corporations whose forex transactions are encouraged by genuine demand/supply are generally those engaging in real sectors (such as Pertamina, PLN, and Indofood), while those that perform trading transactions are financial institutions. 


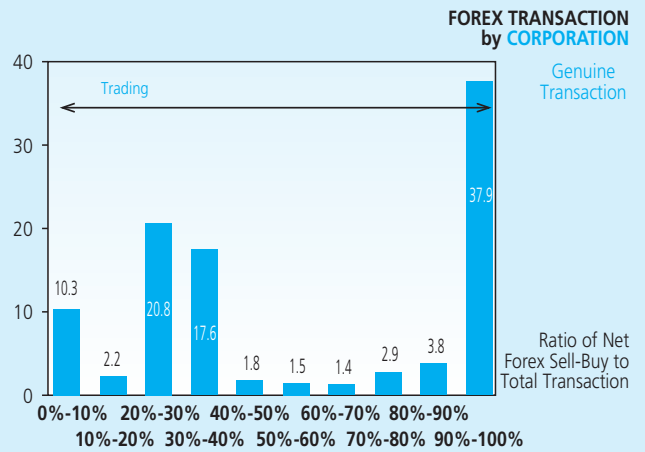

Figure III.9.

Trading Indications by Corporate

Meanwhile, the characters of individual customers cannot be identified since the characteristics of their data are aggregate (no individual data is available).

By considering that almost all foreign players and $50 \%$ of corporations conduct trading transactions, then the transactions of forex markets are dominated by trading transactions with a significant proportion. From one preview, trading transaction makes the forex market is more liquid, but on the other hand, it potentially increases exchange rate volatility. The high trading transaction of foreign participants indicates that the capital inflows are dominated by hot money. Magnitude of hot money flow is confirmed by account financial structure of the balance of payments dominated by the flow of portfolio investments; therefore a more permanent forex supply is rather small. Characteristics of portfolio investments as a short-term investment make the forex market and the domestic financial market is very vulnerable to the risk of capital reversal.

Another specific characteristic of market participants is foreign players playing a role as the market movers. Forex transactions carried out by foreign players tend to be followed by domestic players, (although within an opposite direction because of differences in the base currency), because:

1. The transaction value is fairly large (as explained earlier) so that able to affect or create expectations on future exchange rates. This encourages domestic players to follow it by performing forex transactions to obtain profits.

2. Foreign players who are financial institutions or institutional investors are trusted to conduct a comprehensive analysis by using various analytical methods and relevant information before 
deciding to conduct a transaction. Therefore, most of the domestic players cannot do the same; they tend to follow transactions done by foreign players.

To support the above hypothesis a Granger causality test is conducted by using daily data samples for the periods of January 2004 - April 2009 and intraday data (minute to minute transactions) for several periods representing specific conditions in the forex market. The first is the period of May 2007 that represents a condition in which the forex market experiences net capital inflows in large numbers. April 2008 period is chosen to represent the normal condition of forex market where rupiah moves stabile (low volatility). Conversely, October 2008 period is chosen to represent the forex market condition during the crisis, namely when the sub-prime mortgage crisis in the US (Figure III.10) explodes.

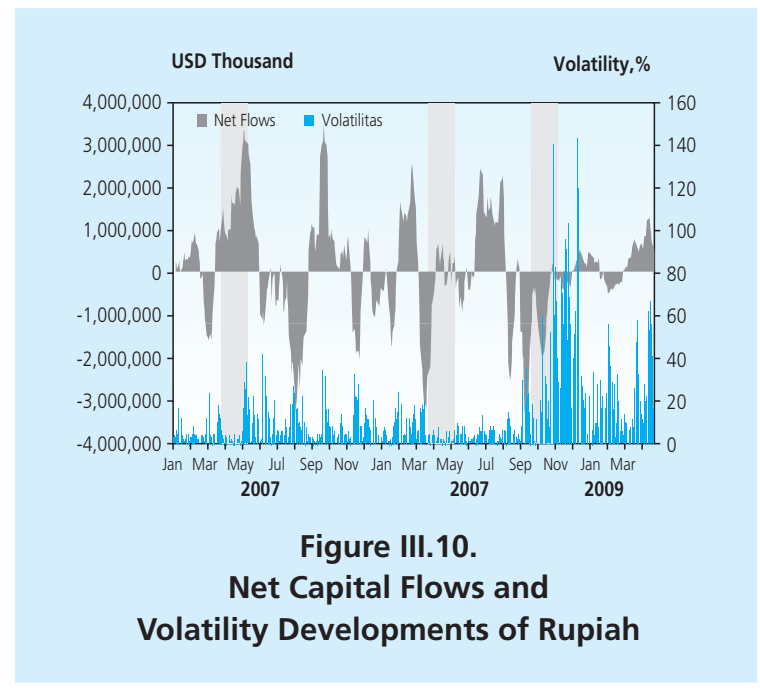

Development of transactions in the forex markets during such three specified periods may be viewed in Table III.3 below. In general, the value of forex transactions of foreign players (with the banks) is much smaller than the transaction value of domestic players, but the average value per transaction is much bigger than the domestic players. One interesting thing is the stable movement of rupiah exchange rate during April 2008 supported by the demand and forex supply from foreign party (net supply) and domestic party (net demand) that are relatively balanced (but the excess supply is $\$ 39$ million). Meanwhile, the rupiah exchange rate during May 2007 period is highlighted by the quite large net supply of foreign players (USD 1,9 billion), hence rupiah tends to be strengthened. Unlike the two periods, the October 2008 period is a crisis period within volatile exchange rates. Forex supply and demand conditions at that time experiences excess demand - both from domestic and foreign players - amounting to $\$ 2,4$ billion. 
Tabel III.3

Forex Transactions Development in Certain Periods

\begin{tabular}{|c|c|c|c|c|c|}
\hline & May-07 & Apr-08 & Oct-08 & \multirow{2}{*}{\multicolumn{2}{|c|}{$\begin{array}{c}\text { Overall Average } \\
\text { (Three Period) }\end{array}$}} \\
\hline \multicolumn{4}{|l|}{ Sale Transactions } & & \\
\hline Bank vs. Foreign Player & & & & Bank vs. Foreign Player & \\
\hline Total Value of Transactions (USD thousands) & $4,378,078$ & $6,111,802$ & $5,135,634$ & Number of Transactions (frequency) & 1,841 \\
\hline Average per transaction (USD thousands) & 3,491 & 4,192 & 3,401 & Value per transaction (USD thousands) & 3,095 \\
\hline Number of Transactions (frequency) & 1,254 & 1,458 & 1,510 & Bank vs. Foreign Player & \\
\hline Bank vs. Domestic Player & & & & Number of Transactions (frequency) & 10,973 \\
\hline Total Value of Transactions (USD thousands) & $25,330,557$ & $19,960,854$ & $19,708,011$ & Value per transaction (USD thousands) & 1,939 \\
\hline Average per transaction (USD thousands) & 2,192 & 1,751 & 1,947 & & \\
\hline Number of Transactions (frequency) & 11,556 & 11,397 & 10,121 & & \\
\hline \multicolumn{6}{|l|}{ Purchase Transactions } \\
\hline \multicolumn{6}{|l|}{ Bank vs. Foreign Player } \\
\hline Total Value of Transactions (USD thousands) & $7,533,516$ & $6,492,548$ & $3,342,554$ & & \\
\hline Average per transaction (USD thousands) & 3,198 & 2,498 & 1,789 & & \\
\hline Number of Transactions (frequency) & 2,356 & 2,599 & 1,868 & & \\
\hline \multicolumn{6}{|l|}{ Bank vs. Domestic Player } \\
\hline Total Value of Transactions (USD thousands) & $24,093,852$ & $19,618,986$ & $19,054,528$ & & \\
\hline Average per transaction (USD thousands) & 2,151 & 1,732 & 1,862 & & \\
\hline Number of Transactions (frequency) & 11,199 & 11,330 & 10,236 & & \\
\hline \multicolumn{6}{|l|}{ Net } \\
\hline Bank VS Foreign Player (USD thousands) & $3,155,438$ & 380,745 & $-1,793,079$ & & \\
\hline Bank VS Domestic Player (USD thousands) & $-1,236,705$ & $-341,868$ & $-653,482$ & & \\
\hline Total Net (USD thousands) & $1,918,734$ & 38,877 & $-2,446,562$ & & \\
\hline
\end{tabular}

Test results for a long period (January 2004 - April 2009) show that forex transactions conducted by foreign players lead to transactions performed by domestic players. In stable and crisis periods, foreign players transactions remain to encourage domestic players transactions, although within confidence level of $10 \%$. Only in the period in which inflows occurs in a large number, domestic players transactions actually influence the foreign players transactions - also within confidence range of $10 \%$.

\begin{tabular}{|c|c|c|c|c|c|c|c|c|}
\hline \multicolumn{9}{|c|}{$\begin{array}{cc}\text { Table III.4 } \\
\text { Causality Test Results: Foreign Players Transaction }\end{array}$} \\
\hline & \multicolumn{2}{|c|}{ Jan 04 to Apr 09} & \multicolumn{2}{|c|}{ May 2007} & \multicolumn{2}{|c|}{ Apr 2008} & \multicolumn{2}{|c|}{ Oct 2008} \\
\hline & F-Stat & Prob. & F-Stat & Prob. & F-Stat & Prob. & F-Stat & Prob. \\
\hline Net Concept (supply/demand) & & & & & & & & \\
\hline $\mathrm{FP} \rightarrow \mathrm{DP}$ & 2,47574 & 0,00453 & 0,38775 & 0,88729 & 1,403 & 0,09995 & 2,44601 & 0,08681 \\
\hline $\mathrm{DP} \rightarrow \mathrm{FP}$ & 1,72918 & 0,06206 & 1,99501 & 0,06298 & 1,142 & 0,29166 & 0,54828 & 0,57800 \\
\hline
\end{tabular}




\section{IV.1.4. Demand and Supply in Forex Markets}

Forex supply and demand may be viewed by market participant group. The corporation group tends to be forex excess or net demand for most of the observed periods. Excess demand of corporations is mainly caused by the high forex demand of some corporations to support their business activities (genuine demand), for instance to finance the imports and the foreign debt payments, compared to the forex supply of some other corporations. Since the forex needs is permanent, then the excess demand resulted tends to be persistent as well.

Similar to the corporation group, individual customers group also tend to experience net demand. However, this group is a little bit more flexible so its frequencies of net supply are quite more often than the corporation group (Figure III.11). Market size of individual customer group is also fairly small compared to the corporation group.

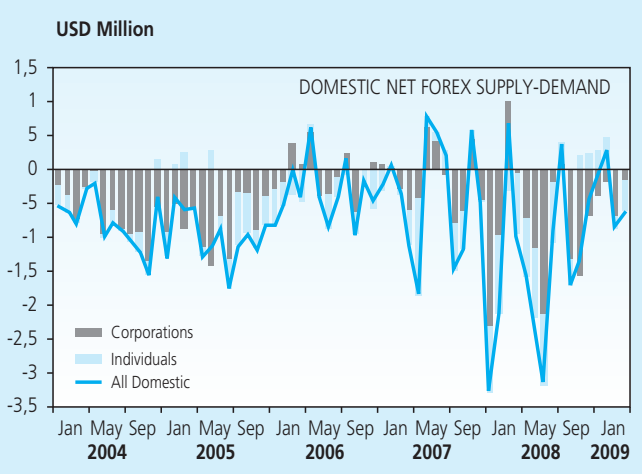

Figure III.11.

Net Forex Supply and Demand of Domestic Players
USD Million

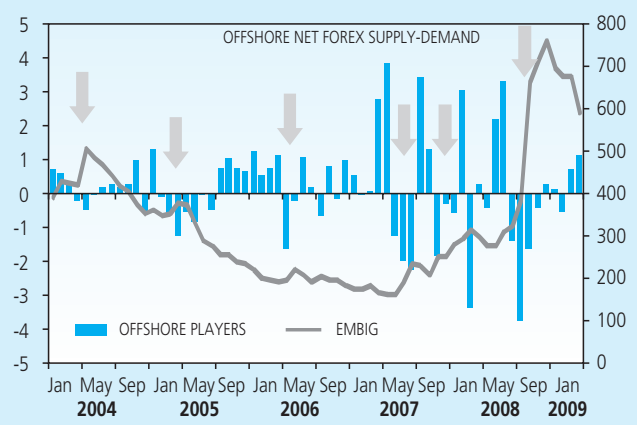

Figure III. 12.

Net Forex Supply and Demand of Domestic Players and EMBIG Index

The characteristics of corporation group that tend to be excess demand may not be apart from the motivation of forex transactions which some are genuine demand/supply so that it is inflexible. The motives of genuine demand/supply transactions are relatively balanced with the more flexible trading motive. Transactions of individual customer group, although they cannot clearly be identified, there are some indications that individual customers more tend to the trading direction.

Different with the domestic player group, the foreign player group plays more as a net supplier of forex that serves as the net demand counterweight of domestic players. Its role as a 
counterweight contributes positive impacts to the exchange rate movement that tends to be stronger and more stable. Although the forex market as a whole is still experiencing excess demand, the forex supply may encourage rupiah appreciation.

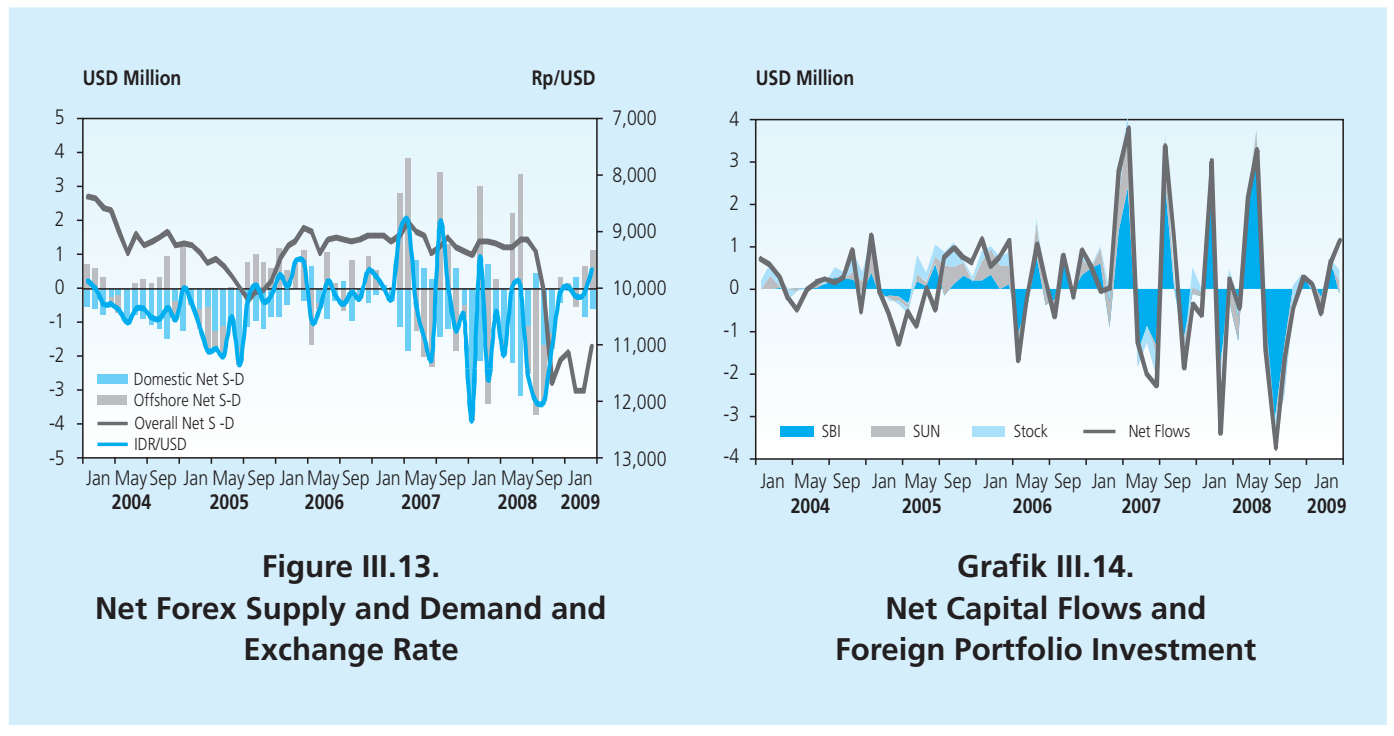

Behind the positive effects of foreign forex supply, there are also inherent problems in this supply, namely the characteristics of foreign fund flow as hot money. Funds of foreign players are placed in rupiah financial asset (portfolio investment), which is very liquid, such as the Bank of Indonesia Certificates (SBI), Government Securities (SUN) and stocks. Figure III.14 shows the development and magnitude of net capital flows that are relatively the same as the foreign portfolio investments in three rupiah financial assets, namely the Bank of Indonesia Certificates (SBI), government securities (SUN) and stocks. Another alternative for foreign investors to invest in Indonesia is by placing their money in the money market or used it in forex trading.

The character of hot money as a very short-term investment is shown in the chart below where inflows and outflows

occur alternately with each other in the fairly similar amount. For example, net inflows occured in the periods of March 2007 - May 2007 reaches USD 6.0 billion, followed by a period of net outflows by nearly similar amount of USD 5.5 billion. 


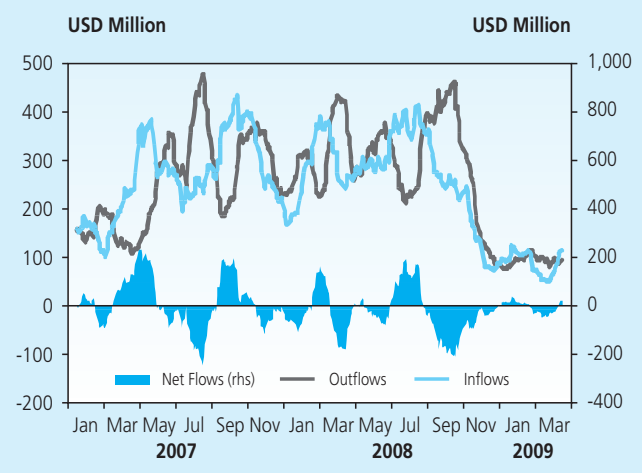

Figure III.15 Net Capital Flows and Foreign Portfolio Investment

As a result of its characteristic as a short-term investment, foreign investors may withdraw their funds at any time, as occurred in some periods where the risk factor increases. When outflows arise, rupiah is depreciated, while its movements are more volatile. Based on the

\begin{tabular}{|c|c|c|}
\hline \multicolumn{3}{|c|}{$\begin{array}{c}\text { Table III.4 } \\
\text { Forex Market Trend during inflows } \\
\text { and outflows Period }\end{array}$} \\
\hline & \multicolumn{2}{|c|}{ EVENT } \\
\hline & Cap. Inflows & Cap. Outflows \\
\hline \# of Events & 708 & 601 \\
\hline $\begin{array}{l}\text { Offshore's Net Fx S-D (avg, \$ mio) } \\
\text { Domestic Net Fx Supply-Demand }\end{array}$ & 97,449 & $-98,761$ \\
\hline Domestic Net Fx Supply & $12.99 \%$ & $56.41 \%$ \\
\hline \# of Events & 92 & 339 \\
\hline Amount (avg, \$ mio) & 33.46 & 78.62 \\
\hline Domestic Net Fx Demand & $87.01 \%$ & $43.59 \%$ \\
\hline \# of Events & 616 & 262 \\
\hline Amount (avg, \$ mio) & -101.48 & -56.63 \\
\hline Exchange Rate Novements & & \\
\hline Appreciation & $66.08 \%$ & $29.29 \%$ \\
\hline \# of Events & 450 & 169 \\
\hline Average & $0.43 \%$ & $0.28 \%$ \\
\hline Depreciation & $33.92 \%$ & $70.71 \%$ \\
\hline \# of Events & 231 & 408 \\
\hline Average & $-0.26 \%$ & $-0.50 \%$ \\
\hline Exch. Rate Volatility (avg) & $10.25 \%$ & $12.14 \%$ \\
\hline
\end{tabular}

\begin{tabular}{|c|c|c|}
\hline \multicolumn{3}{|c|}{$\begin{array}{c}\text { Table III.5 } \\
\text { Forex Market Trend during Appreciation } \\
\text { and Depreciation Periods }\end{array}$} \\
\hline & \multicolumn{2}{|c|}{ EVENT } \\
\hline & Appreciation & Depreciation \\
\hline \# of Events & 670 & 639 \\
\hline$\%$ change (avg) & $0.36 \%$ & $-0.41 \%$ \\
\hline Exch. Rate Volatility (avg) & $10.76 \%$ & $11.50 \%$ \\
\hline \multicolumn{3}{|l|}{ Domestic Net Fx Supply-Demand } \\
\hline Domestic Net Fx Supply & $15.97 \%$ & $0.70 \%$ \\
\hline \# of Events & 107 & 324 \\
\hline Amount (avg, \$ mio) & 45.46 & 76.75 \\
\hline Domestic Net Fx Demand & $84.03 \%$ & $49.30 \%$ \\
\hline \# of Events & 563 & 315 \\
\hline Amount (avg, \$ mio) & -102.95 & -61.53 \\
\hline \multicolumn{3}{|l|}{ Capital Flows (Offshore Net S-D) } \\
\hline Capital Inflows & $71.19 \%$ & $36.15 \%$ \\
\hline \# of Events & 477 & 231 \\
\hline Avg., \$ mio & 117.96 & 55.09 \\
\hline Capital Outflows & $28.81 \%$ & $63.85 \%$ \\
\hline \# of Events & 193 & 408 \\
\hline Average & -68.35 & -113.15 \\
\hline
\end{tabular}


historical data, in the event of inflows, there is $66 \%$ chance of rupiah appreciation, whereas the appreciation occurred is relatively smooth so that the volatility resulted is on the average of $10 \%$ only. However, when outflows occur, the opportunity of rupiah depreciation is slightly larger (71\%) and the level of depreciation is much sharper as reflected in the average volatility of outflow period that achieves approximately $12 \%$. From the above description, the asymmetric impact of the inflows and outflows may be seen. One of the factors that cause such asymmetric impact is the domestic supply and demand conditions that tend to be excess demand. Therefore, the foreign forex supply must firstly mend the domestic excess demand before encouraging the rupiah appreciation.

\section{IV.1.5. Transaction Pattern Between the Market Participant Groups}

Forex transactions conducted by forex market participants formulate a general pattern that is fairly persistent in the observed periods. In addition, although it is not able to identify the occurrence of market segmentation, such transaction pattern indicates that the market is only dominated by a small part of market players. In the market maker group, the market is controlled by foreign banks (by six banks only), government banks (three banks) and only few banks from the joint bank group ( 1 bank) and private forex bank. These banks control around $86 \%$ of the market share, while the remaining is contested by more than 100 other domestic banks.

Associated with the transaction pattern, foreign banks become the biggest bank group which have access to all market participants. In fact, more than $80 \%$ of bank transactions with foreign players are served by foreign banks, so that foreign banks become the 'gate' of foreign players to enter the domestic financial market. Under normal circumstances, foreign players become the forex suppliers for foreign banks and other banking groups. In addition, foreign banks also receive larger forex supply from corporations. Forex supply is almost exclusively distributed by foreign banks to other banks, especially state banks and private forex banks. Overall, foreign banks experience sufficiently large excess demand.

Limited liability company banks, in addition to receiving forex supply from foreign players (directly) and foreign banks, they also gain a large amount of forex supply from individual customers. The forex supply is distributed to meet the forex demand of corporations (including Pertamina), which is very large, so that the overall state banks also experiences forex flow deficit.

The only banks group experiencing a surplus of forex supply is the private forex banks. This group receive a forex supply from all groups of banks, except the private non-forex banks, 


\begin{tabular}{|c|c|c|c|c|c|c|}
\hline \multicolumn{7}{|c|}{$\begin{array}{c}\text { Table III. } 6 \\
\text { Forex Transaction Pattern Between the Market Participant Groups }\end{array}$} \\
\hline & \multirow[b]{2}{*}{ ALL Period } & \multicolumn{5}{|c|}{ NET FOREX BUY and SELL BY } \\
\hline & & $\begin{array}{l}\text { FOREIGN } \\
\text { BANK }\end{array}$ & JOINT BANK & STATE BANK & $\begin{array}{l}\text { PRIVATE FX } \\
\text { BANK }\end{array}$ & ALL BANK \\
\hline \multirow{10}{*}{ 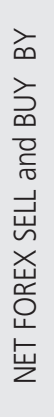 } & FOREIGN BANK & 0 & $-756,207$ & $3,985,576$ & $16,813,438$ & $20,042,807$ \\
\hline & JOINT BANK & 663,807 & 0 & $-1,607,367$ & $11,019,864$ & $10,076,304$ \\
\hline & STATE BANK & $-3,985,576$ & $1,551,367$ & 0 & $10,361,111$ & $7,926,902$ \\
\hline & PRIVATE FX BANK & $-16,817,638$ & $-11,078,014$ & $-10,361,111$ & 0 & $-38,256,763$ \\
\hline & REG DEVL BANK & $-548,785$ & $-1,750$ & 193,175 & 588,686 & 231,326 \\
\hline & PRIVATE Non-FX BANK & $-629,034$ & $-602,332$ & $-454,428$ & $-328,135$ & $-2,013,929$ \\
\hline & CORPORATION & $11,404,656$ & $5,020,344$ & $-48,475,487$ & $-3,142,302$ & $-35,192,789$ \\
\hline & INDIVIDUAL & $-2,076,875$ & 862,379 & $11,558,071$ & $-24,633,484$ & $-14,289,909$ \\
\hline & OFFSHORE & $2,421,232$ & $2,212,527$ & $2,736,218$ & $2,916,468$ & $10,286,445$ \\
\hline & & $-9,568,213$ & $-2,791,686$ & $-42,425,353$ & $13,595,646$ & \\
\hline
\end{tabular}

\begin{tabular}{|c|c|c|c|c|c|c|}
\hline & \multirow[b]{2}{*}{ ALL Period } & \multicolumn{5}{|c|}{ NET FOREX BUY and SELL BY } \\
\hline & & $\begin{array}{l}\text { FOREIGN } \\
\text { BANK }\end{array}$ & JOINT BANK & STATE BANK & $\begin{array}{c}\text { PRIVATE FX } \\
\text { BANK }\end{array}$ & ALL BANK \\
\hline \multirow{10}{*}{ 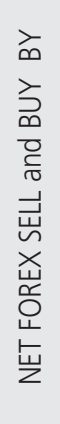 } & FOREIGN BANK & 0 & $-679,223$ & $-1,859,500$ & $-567,760$ & $-3,106,483$ \\
\hline & JOINT BANK & 679,223 & 0 & $-1,327,475$ & 809,148 & 160,896 \\
\hline & STATE BANK & $1,859,500$ & $1,327,475$ & 0 & $1,929,275$ & $5,116,250$ \\
\hline & PRIVATE FX BANK & 567,760 & $-809,148$ & $-1,929,275$ & 0 & $-2,170,663$ \\
\hline & REG DEVL BANK & 41,365 & 0 & $-35,060$ & 12,150 & 18,455 \\
\hline & PRIVATE Non-FX BANK & $-46,811$ & $-114,680$ & $-102,200$ & $-46,737$ & $-310,428$ \\
\hline & CORPORATION & 229,960 & $-11,399$ & $-2,780,567$ & $-893,360$ & $-3,455,366$ \\
\hline & INDIVIDUAL & 85,342 & $-23,719$ & 425,388 & $-264,810$ & 222,201 \\
\hline & OFFSHORE & $-2,671,868$ & 500,799 & 100,839 & 267,014 & $-1,803,216$ \\
\hline & & 744,471 & 190,105 & $-7,507,850$ & $1,244,920$ & \\
\hline
\end{tabular}

and the foreign players directly. The forex supply is utilized to meet the forex demands of corporations and individual customers, while the surplus increases the forex reserves of this bank group.

In crisis conditions, as happened in the last quarter of 2008, the flow pattern direction of forex transactions as described above is reversed, so that foreign bank group and joint bank group experience an excess supply. Meanwhile, the state banks continue to have deficits (as in normal conditions) and the private forex banks experience a supply surplus. This condition indicates an imbalance distribution of forex, although it is still possible to be balanced through various other channels, such as transfers of funds or through PUAB. 


\section{IV.2. Estimate Results}

\section{IV.2.1. Exchange Rate Equation}

In accordance with the processing result by using the ECM method, factors influencing the exchange rate both in long and short terms are recognized. For a long term, the net forex supply from foreign players is the only factor affecting the exchange rate movement. $1 \%$ increase in the net forex supply of foreign players will lead to the exchange rate appreciation of $0.06 \%$.

Meanwhile, for a short term, risk factor is the main factor influencing the exchange rate movement. Regression coefficient of risk factor of 0.70 that implies each worse risk where the risk index increase of $1 \%$ will cause rupiah exchange rate depreciation of $0.70 \%$. The processing results show that the sentiment of market participants to the forex market is still dominated.

The second factor significantly influencing is the regional exchange rate movement of 0.46 . The regional exchange rate indexes are the composite indexes of Japanese, Europe, and Singapore currencies, which represent the regional exchange rates. Nugroho et .all (2008) show that the movements of such four currencies have strong correlation with rupiah movements, as shown in the following chart.

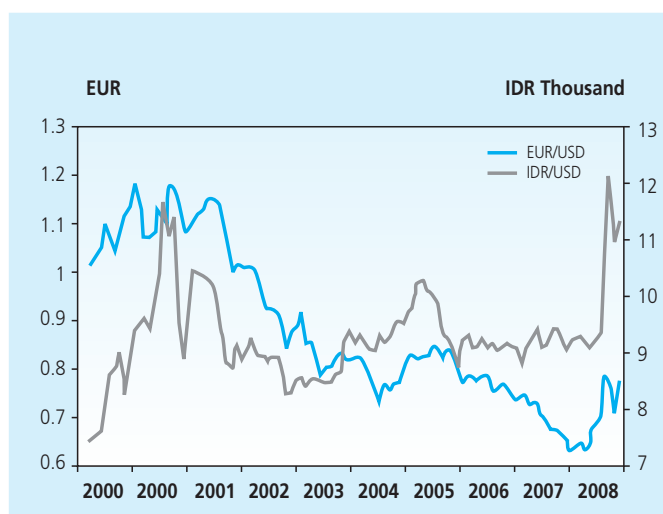

Figure III.16.

Development of Rupiah and Euro Exchange Rates

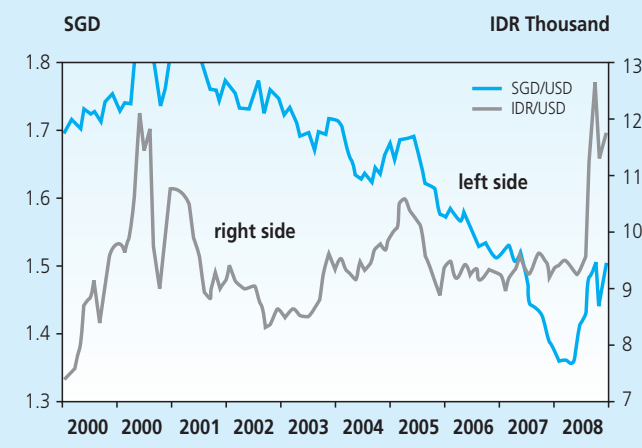

Figure III.17.

Development of Rupiah and Singapore Dollar Exchange Rates

Moreover, the demand and supply factors affect the exchange rates significantly within composition as follows: 
a. Foreign demand and supply influence the coefficient of 0.06 in the current period and 0.04 in the past. The temporary influence of supply and demand is greater in the present. These results are consistent with the theory of simultaneous-trade model that the current behaviour of market participants is information for the future market participants who will then perform a similar behaviour. In addition, these results are also consistent with the previous analysis that shows the influence of domestic player's behaviour to the foreign players. This means that the greater coefficient of today is the accumulation of current information and past player information for among foreign players and domestic players.

b. Domestic supply and demand affect the current coefficient of 0.05 . Past behaviour does not affect the current condition, showing that all market information has been absorbed in period t. However, it is necessary to consider that the effects of domestic supply and demand are smaller than the foreign demand and supply. This test clarifies the results of the previous analysis. Market share of foreign players in forex trading within a denomination of USD/IDR is still in the range of $40 \%$ and uses foreign banks in carrying out the transactions. Meanwhile, the relevance of foreign banks as the main partner of domestic banks increases. Large magnitude of foreign players to domestic players may also come from the trading behaviour tendency of foreign players, so that greater changes in exchange rates show greater expected gain/loss for foreign players as well. Meanwhile, domestic players tend to make real transactions, thus the forex purchases and sales are not only influenced by changes in the exchange rates, but it is also due to forex needs.

The following table shows the test results of an exchange rate model (by fulfilling the BLUE assumption) in long and short terms.

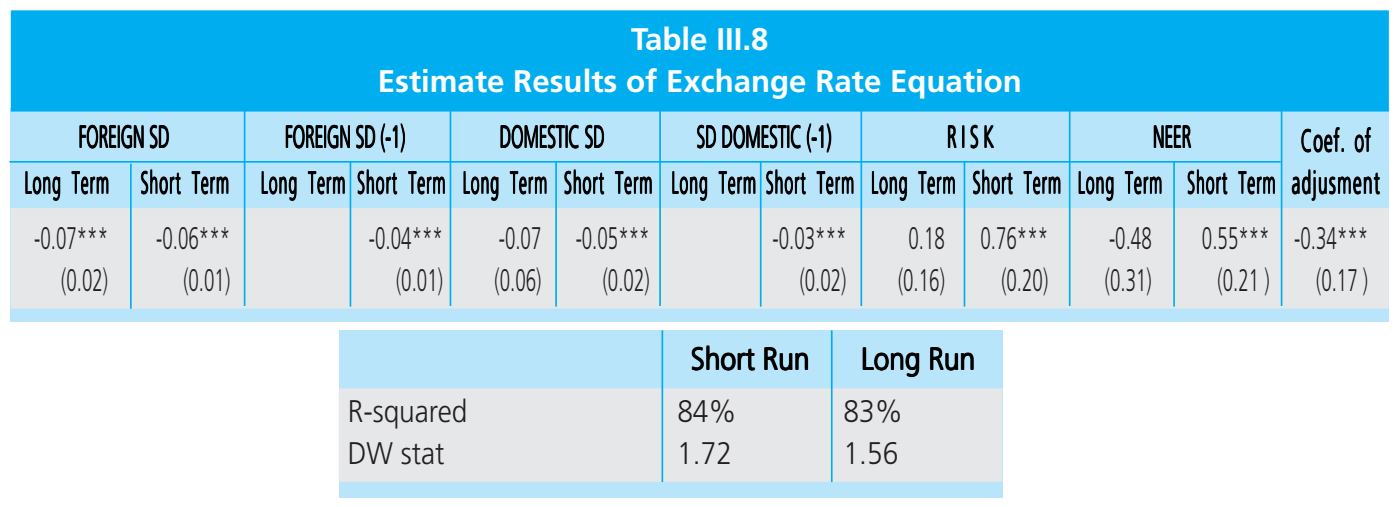




\section{IV.2.2. Output Equation}

Output equation is an identity function of the variables of consumption, investment, government, exports, and imports. Variables of consumption, investment and government are exogenous variables in the formation of output, while variables of imports and exports are specified in the (endogenous) model.

\section{a. Export}

As described in the methodology, the export equation used is the function of exchange rates, revenue of trading partner, and terms of trade (the export prices compared to the import prices). In the export equation, a processing method using ECM is conducted also since some exogenous variables are not stationary in the level but have a long-term cointegration. ${ }^{2}$ Processing results in the long term show that the growth variable of trading partner (growth composite of major trading partners such as Japan, USA, and Singapore) is the main factor affecting Indonesia's exports. This is in accordance with the fact that these three countries own shares that reach $44.58 \%$ of the total Indonesia's exports. High concentration of those three countries results in strong dependence of Indonesia's exports on them.

Meanwhile, for a short term, the most export movement influencing factor is the price factor shown by the terms of trade. $1 \%$ increase of export price (relative to the import price) causes a decrease of exports amounting to $2.2 \%$.

Furthermore, the other export affecting factor is the change of exchange rates. Exchange rate depreciation will cause the price of exported goods in the international market is relatively cheaper, thereby, it may increase the exports. Moreover, the coefficient of data processing is 1.185 , in which $1 \%$ increase of exchange rate will cause $1.19 \%$ increase of exports. This equation also shows the effect of exchange rates to the exports directly or indirectly. The indirect way is through the more expensive price of imported goods due to the increase of exchange rates; therefore, the price of exported goods becomes cheaper and ultimately enhances the exports.

The test results of exchange rate model (by satisfying the BLUE assumption) both in long and short terms may be concluded as the following table: 


\begin{tabular}{|c|c|c|c|c|c|c|}
\hline \multicolumn{7}{|c|}{$\begin{array}{l}\text { Table III.9. } \\
\text { Estimate Results of Export Equation }\end{array}$} \\
\hline \multicolumn{2}{|c|}{ Term of Trade } & \multicolumn{2}{|c|}{ Production Index } & \multicolumn{2}{|c|}{ Exchange Rate } & \multirow{2}{*}{$\begin{array}{l}\text { Coef. of } \\
\text { adjusment }\end{array}$} \\
\hline Long Term & Short Term & Long Term & Short Term & Long Term & Short Term & \\
\hline \multirow[t]{3}{*}{$\begin{array}{l}-0.65 \\
(0.56)\end{array}$} & $\begin{array}{l}-2.2^{*} \\
(1.23)\end{array}$ & $\begin{array}{r}1.91 * * * \\
(0.35)\end{array}$ & $\begin{array}{r}0.57 \\
(0.50)\end{array}$ & $\begin{array}{r}0.21 \\
(0.18)\end{array}$ & $\begin{array}{l}1.19 * \\
(0.64)\end{array}$ & $\begin{array}{r}-0.61 * * * \\
(0.15)\end{array}$ \\
\hline & & & Short Run & Long Run & & \\
\hline & $\begin{array}{l}\text { R-squ } \\
\text { DW s }\end{array}$ & & $\begin{array}{l}60 \% \\
2.06\end{array}$ & $\begin{array}{l}64 \% \\
2.18\end{array}$ & & \\
\hline
\end{tabular}

b. Import

Import equation is also the functions of exchange rate, terms of trade (export prices compared with import prices), and growth of Indonesia. Based on the processing results by using the ECM, it is obtained that for the long term the most influencing factor to the movement of imports in Indonesia is the relative price between the exports and the imports. $1 \%$ increase of the terms of trade may cause a 1.25\% decrease of imports. Meanwhile, in the short term, the most influencing factor to the imports is the change of exchange rates. $1 \%$ depreciation of exchange rate may lead to $1 \%$ decrease of imports as well. Another factor that affects the movement of imports is the economic growth, in which 1\% increase of Indonesia's economic growth causes an increase of imports amounting to $0.64 \%$. Unlike the previous export equation, which indicates a direct effect of exchange rates to the exports and the exchange rate effects are transmitted through the terms of trade, in this import equation, the effects of exchange rate have direct impacts to the import movements, while for the short term there are no indirect effects through the terms of trade.

The test results of the exchange rate model (by satisfying the BLUE assumption) both in long and short terms may be concluded in the following table:

\begin{tabular}{|c|c|c|c|c|c|c|}
\hline \multicolumn{7}{|c|}{$\begin{array}{l}\text { Table III.10. } \\
\text { Estimate Results of Import Equation }\end{array}$} \\
\hline \multicolumn{2}{|c|}{ Term of Trade } & \multicolumn{2}{|c|}{ Production Index } & \multicolumn{2}{|c|}{ Exchange Rate } & \multirow{2}{*}{$\begin{array}{l}\text { Coef. of } \\
\text { adjusment }\end{array}$} \\
\hline Long Term & Short Term & Long Term & Short Term & Long Term & Short Term & \\
\hline \multirow[t]{3}{*}{$\begin{array}{r}-1.25^{* *} \\
(0.56)\end{array}$} & $\begin{array}{r}0.87 \\
(0.58)\end{array}$ & $\begin{array}{r}0.15 \\
(0.29)\end{array}$ & $\begin{array}{r}0.65^{* * *} \\
(0.08)\end{array}$ & $\begin{array}{r}0.06 \\
(0.30)\end{array}$ & $\begin{array}{r}-1.00^{* *} \\
(0.38)\end{array}$ & $\begin{array}{r}-0.44^{* * *} \\
(0.08)\end{array}$ \\
\hline & & & Short Run & Long Run & & \\
\hline & $\begin{array}{l}\text { R-squ } \\
\text { DW s }\end{array}$ & $\begin{array}{l}\text { ired } \\
\text { at }\end{array}$ & $\begin{array}{l}76 \% \\
2.52\end{array}$ & $\begin{array}{l}86 \% \\
2.57\end{array}$ & & \\
\hline
\end{tabular}




\section{IV.3.2. Price Equation}

\section{a. Import prices}

This equation is used to view the relationship between exchange rates and prices of imports. The test results by using ECM shows that in the long term, the most influencing factor to Indonesia's import prices is

the international prices, in which $1 \%$ increase of international prices leads to an increase in import prices of $0.99 \%$. The second factor affecting the long term is the change of exchange rate, with the effect of 0.42 . This exchange rate pass-through figure is consistent with the findings of Kurniati (2008) obtaining the exchange rates affect against import prices of 0.45 at a post-crisis period.

Meanwhile, in the short term, exchange rate is most influencing factor to the import prices within a coefficient of $0.33^{3}$, followed by the supply shock factor (oil price) with a coefficient of 0.20 . When compared with the previous study, the effects of exchange rate to the import price movements increasingly get higher, especially in the short term. It means that, as mentioned earlier due to the large magnitude of foreign supply and demand against exchange rate, it will also impacts the import price pressures.

The test results of exchange rate model (by satisfying the BLUE assumption) both in long and short terms may be concluded in the following table:

\begin{tabular}{|c|c|c|c|c|c|c|c|c|c|}
\hline \multicolumn{10}{|c|}{$\begin{array}{l}\text { Tabel III.11. } \\
\text { Estimate Results of Import Price Equation }\end{array}$} \\
\hline \multicolumn{2}{|c|}{ International Price } & \multicolumn{2}{|c|}{ Exchange Rate } & \multicolumn{3}{|c|}{ Supply Stock } & \multicolumn{2}{|c|}{ GDP } & \multirow{2}{*}{$\begin{array}{l}\text { Coef. of } \\
\text { adjusment }\end{array}$} \\
\hline Long Term & Short Term & Long Term & Short Term & Long Term & Short & Term & Long Term & Short Term & \\
\hline \multirow[t]{3}{*}{$\begin{array}{r}0.99 * * \\
(0.39)\end{array}$} & $\begin{array}{r}0.67 \\
(0.61)\end{array}$ & $\begin{array}{r}0.42 * * * \\
(0.13)\end{array}$ & $\begin{array}{r}0.33^{* * *} \\
(0.08)\end{array}$ & $\begin{array}{r}0.20 * * * \\
(0.03)\end{array}$ & 0.2 & $\begin{array}{l}* * * \\
.03)\end{array}$ & $\begin{array}{r}0.02 \\
(0.02)\end{array}$ & $\begin{array}{r}0.01 \\
(0.02)\end{array}$ & $\begin{array}{r}-0.26^{* *} \\
(0.12)\end{array}$ \\
\hline & & & & \multicolumn{2}{|c|}{ Short Run } & \multicolumn{2}{|c|}{ Long Run } & & \\
\hline & & $\begin{array}{l}\text { R-squa } \\
\text { DW sta }\end{array}$ & & \multicolumn{2}{|l|}{$73 \%$} & \multicolumn{2}{|c|}{$\begin{array}{l}99 \% \\
2.06\end{array}$} & & \\
\hline
\end{tabular}

3 The results of Kurniati's (2008) study found exchange rate pass through for 0.20 in short term during a post-crisis period. 


\section{b. Customer Prices}

The second round effect by the presence of changes in exchange rates is pressure on overall prices. Because of such increased prices of imported goods, the overall prices of the economy increase as well. In the long term, the price influencing factor of the economy is Indonesia's economic growth, namely $1 \%$ increase of economic growth causes $0.01 \%$ increase of price. Meanwhile, in the short term, changes in the domestic prices are caused by the increased price of imported goods, namely $1 \%$ increase of imported goods price may cause $0.05 \%$ increase of domestic prices. The analysis result presents the existence of the high level of import dependence for the overall production activities.

\begin{tabular}{|l|l|c|}
\multicolumn{2}{|c}{$\begin{array}{c}\text { Table III.12. } \\
\text { No. }\end{array}$} & \multicolumn{1}{|c}{ Commodities } \\
\hline 1 & Oil and its derivates & $\begin{array}{c}\text { Average Share } \\
(\mathbf{2 0 0 0 - 2 0 0 8 )}\end{array}$ \\
2 & Organic chemicals & $28 \%$ \\
3 & Iron and steel & $8 \%$ \\
4 & Industrial machinery and the equipments & $6 \%$ \\
5 & Special industrial machinery & $6 \%$ \\
6 & Wheat and processed wheat & $5 \%$ \\
7 & Plastic materials & $3 \%$ \\
8 & Engine power & $3 \%$ \\
9 & Textile fibres and the remaining & $3 \%$ \\
10 & Weaving yarn, textile fabrics, and the products & $3 \%$ \\
11 & Other chemicals & $3 \%$ \\
12 & Pulp and Paper & $3 \%$ \\
13 & Ferrous metal & $2 \%$ \\
14 & Other metal items & $2 \%$ \\
15 & Animal feeds & $2 \%$ \\
16 & Inorganic chemicals & $2 \%$ \\
17 & Metal ores and metal remnants & $1 \%$ \\
18 & Dyes and other colouring & $1 \%$ \\
19 & Sugar, refined sugar and & $1 \%$ \\
20 & Honeymilk and egg products & $1 \%$ \\
& & $1 \%$ \\
\hline
\end{tabular}

When viewing the table III. 12 above in more details, the main imported goods coming to Indonesia are mostly consist of the main goods of manufacturing industry, such as oil and processed products, organic chemicals, iron and steel. These goods are the main commodity of industrial production in Indonesia, so in case any subsequent change of exchange rates leads to 
increased pressure of import prices, they will also give strong impacts to the domestic prices. The test results of exchange rate model (by satisfying the BLUE assumption) both in long and short terms may be concluded in the following table.

\begin{tabular}{|c|c|c|c|c|c|c|}
\hline \multicolumn{7}{|c|}{$\begin{array}{l}\text { Table III.13. } \\
\text { Estimate Results of Customer Price Equation }\end{array}$} \\
\hline \multicolumn{2}{|c|}{ Import Price } & \multicolumn{2}{|c|}{ GDP } & \multicolumn{2}{|c|}{ Supply Shock } & \multirow{2}{*}{$\begin{array}{l}\text { Coef. of } \\
\text { adjusment }\end{array}$} \\
\hline Long Term & Short Term & Long Term & Short Term & Long Term & Short Term & \\
\hline $\begin{array}{l}-0.01 \\
(0.02)\end{array}$ & $\begin{array}{l}0.05^{*} \\
(0.03)\end{array}$ & $\begin{array}{r}-0.01 * * * \\
(0.00)\end{array}$ & $\begin{array}{r}0.00 \\
(0.00)\end{array}$ & $\begin{array}{r}-0.00 \\
(0.00)\end{array}$ & $\begin{array}{r}0.01 \\
(0.01)\end{array}$ & $\begin{array}{l}-0.08 \\
(0.20)\end{array}$ \\
\hline
\end{tabular}

\begin{tabular}{l|l|l} 
& Short Run & Long Run \\
R-squared & $85 \%$ & $99 \%$ \\
DW stat & 1.81 & 2.22
\end{tabular}

\section{IV.2.4. Simultaneous Model Simulation}

Based on the incorporation of partial models, it is obtained an adjustment result between the baseline and the actual as viewed in Figure III.18. From such figure, it may be seen that most of the baseline (data on estimates of the partial models) may estimate the magnitude of actual figures. For the equations of exchange rates, import prices and domestic prices, the partial equations are able to capture the actual data movement well. However, during some periods, especially for the export equation, the partial models cannot capture the actual data movement perfectly although the direction the actual data movement may fairly be captured.

Furthermore, from the results of processing using a simultaneous model, several simulations are performed, especially related to the increase/decrease of domestic and overseas forex demand and supply such as follows:

1. The scenario of changes in the demand and forex supply is in the form of forex supply and demand increase that reaches $20 \%$. The simulation of a forex supply increase of $20 \%$ coming from foreign players causes the exchange rate appreciation of $4.44 \%$ followed by changes in the other macro variables. Similarly, $20 \%$ increase of forex demand generated from the abroad may also lead to the exchange rate depreciation of $4.68 \%$ followed by changes in other macro variables. Based on the data processing results, it may be seen that the impacts of foreign forex supply increase are smaller than the impacts of foreign forex demand increase. This shows a greater opportunity on the rupiah depreciation for each increase of foreign forex demand. 
ER

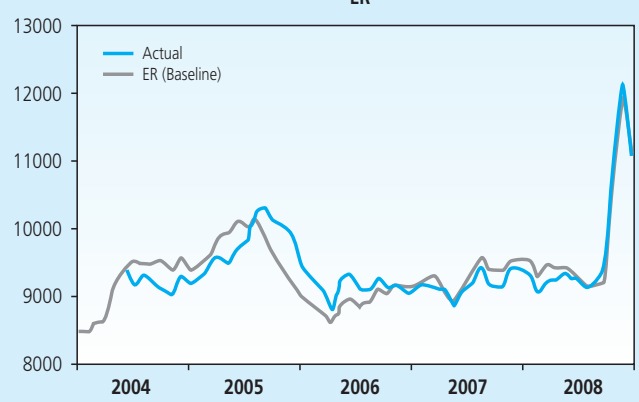

P

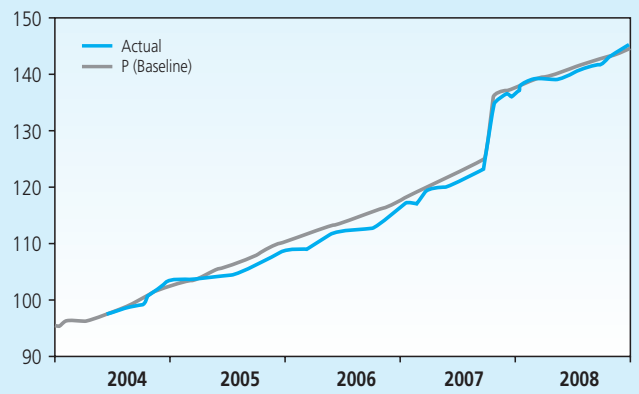

$\mathrm{X}$

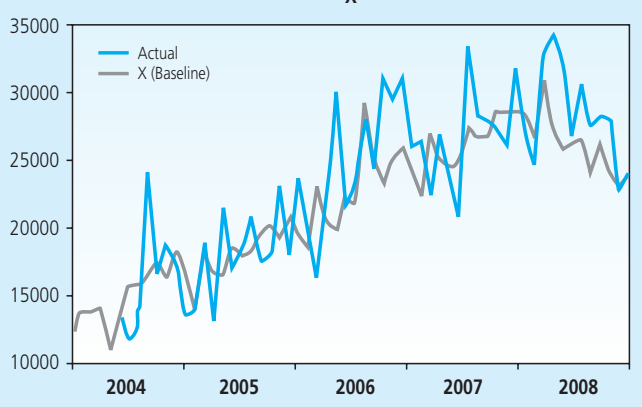

M

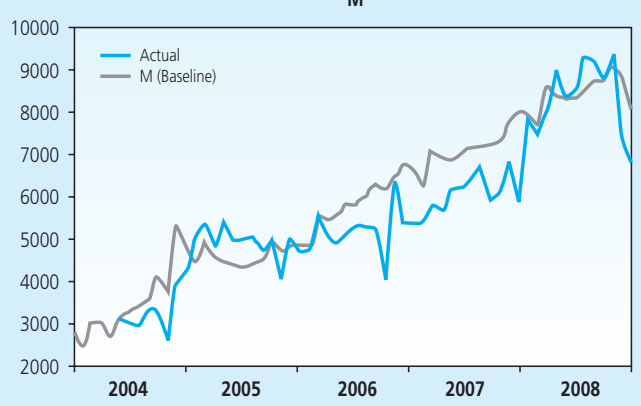

PM

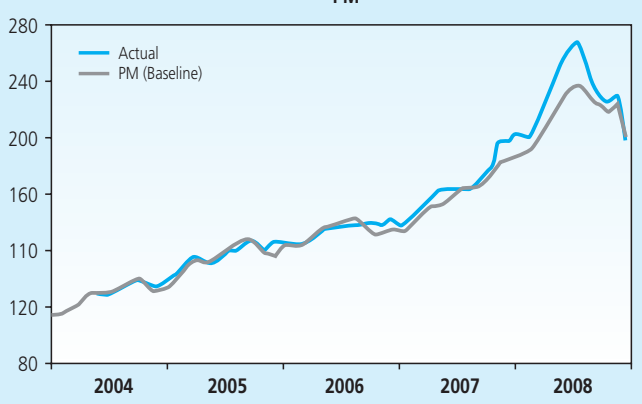

Y

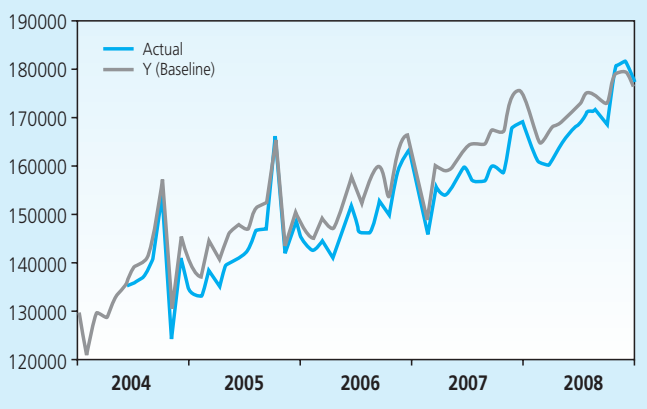

Figure III.18.

Simultaneous Model of 6 Partial Equations

When viewing the impacts of other macroeconomic variables, it may be seen that the impacts of depreciation contributes higher to the export variables, while appreciation contributes greater to the import variables. Furthermore, other variables such as GDP, import prices and domestic prices have the same effects at the time of appreciation or depreciation. Entirely, the simulation results of two scenarios may be seen in the table below: 


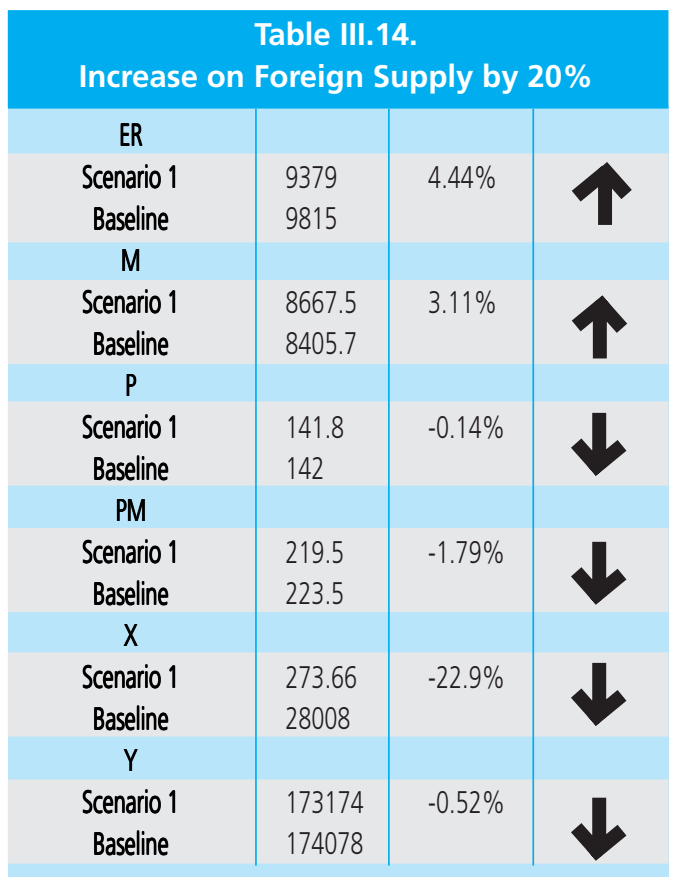

\begin{tabular}{c|c|c|}
\hline \multicolumn{3}{|c}{ Table III.15. } \\
\hline Increase on Foreign Demand by $20 \%$ \\
ER & & \\
Scenario 2 & 10274 & $4.68 \%$ \\
Baseline & 9815 & \\
M & & \\
Scenario 2 \\
Baseline & 8155.6 & $-2.98 \%$ \\
P & 8405.7 & \\
Scenario 2 & 142.2 & $0.14 \%$ \\
Baseline & 142 & \\
PM & & \\
Scenario 2 \\
Baseline & 227.5 & $1.79 \%$ \\
X & 223.5 & \\
Scenario 98152 & 28669 & $2.36 \%$ \\
Baseline & 28008 & \\
Y & & \\
Scenario 2 & 174989 & 0.52 \\
Baseline & 174078 & \\
\hline
\end{tabular}

2. The change scenario of demand and forex supply is in the form of forex supply and demand decrease that reaches $20 \%$. Based on the simulation of such scenario, it may be seen that the impact of forex supply decreased by foreign parties (leading to rupiah depreciation) is

\begin{tabular}{|c|c|c|c|}
\hline \multicolumn{4}{|c|}{$\begin{array}{c}\text { Table III. } 16 . \\
\text { Decline on Foreign Supply by } 20 \%\end{array}$} \\
\hline ER & & & \\
\hline $\begin{array}{c}\text { Scenario } 3 \\
\text { Baseline }\end{array}$ & $\begin{array}{l}10381 \\
9815\end{array}$ & $5.77 \%$ & \\
\hline M & & & \\
\hline $\begin{array}{l}\text { Scenario } 3 \\
\text { Baseline }\end{array}$ & $\begin{array}{l}8101.2 \\
8405.7\end{array}$ & $-3.62 \%$ & \\
\hline$p$ & & & \\
\hline $\begin{array}{l}\text { Scenario } 3 \\
\text { Baseline }\end{array}$ & $\begin{array}{l}142.2 \\
1.42\end{array}$ & $0.14 \%$ & \\
\hline PM & & & \\
\hline $\begin{array}{c}\text { Scenario } 3 \\
\text { Baseline }\end{array}$ & $\begin{array}{l}228.4 \\
223.5\end{array}$ & $2.19 \%$ & \\
\hline$x$ & & & \\
\hline $\begin{array}{c}\text { Scenario } 3 \\
\text { Baseline }\end{array}$ & $\begin{array}{l}28820 \\
28008\end{array}$ & $2.90 \%$ & \\
\hline$Y$ & & & \\
\hline $\begin{array}{l}\text { Scenario } 3 \\
\text { Baseline }\end{array}$ & $\begin{array}{l}175195 \\
1740781\end{array}$ & $0.64 \%$ & \\
\hline
\end{tabular}

\begin{tabular}{|c|c|c|c|}
\hline \multicolumn{4}{|c|}{$\begin{array}{c}\text { Table III. } 17 . \\
\text { Decline on Foreign Demand by } 20 \%\end{array}$} \\
\hline$E R$ & & & \\
\hline $\begin{array}{c}\text { Scenario } 4 \\
\text { Baseline }\end{array}$ & $\begin{array}{l}9285 \\
9815\end{array}$ & $-5.40 \%$ & \\
\hline$M$ & & & \\
\hline $\begin{array}{l}\text { Scenario } 4 \\
\text { Baseline }\end{array}$ & $\begin{array}{l}8727.8 \\
8405.7\end{array}$ & $3.83 \%$ & \\
\hline$p$ & & & \\
\hline $\begin{array}{l}\text { Scenario } 4 \\
\text { Baseline }\end{array}$ & $\begin{array}{l}141.8 \\
142\end{array}$ & $-0.14 \%$ & \\
\hline PM & & & \\
\hline $\begin{array}{c}\text { Scenario } 4 \\
\text { Baseline }\end{array}$ & $\begin{array}{l}218.6 \\
223.5\end{array}$ & $-2.19 \%$ & \\
\hline$x$ & & & \\
\hline $\begin{array}{c}\text { Scenario } 4 \\
\text { Baseline }\end{array}$ & $\begin{array}{l}27225 \\
28008\end{array}$ & $-2.80 \%$ & \\
\hline$Y$ & & & \\
\hline $\begin{array}{c}\text { Scenario } 4 \\
\text { Baseline }\end{array}$ & $\begin{array}{l}172973 \\
174078\end{array}$ & $0.63 \%$ & \\
\hline
\end{tabular}


greater than the impact of forex demand decrease. Similar to the first scenario, it may be viewed that the impact of rupiah depreciation more influences the exports, while rupiah appreciation more influences the imports.

3. The change scenario of domestic demand and forex supply is in the form of $20 \%$ increase of forex supply and $20 \%$ increase of foreign currency demand. The amount of depreciation caused by an increase of domestic forex demand amounting to $0.79 \%$ is greater than the appreciation due to the increase of foreign forex supply amounting to $0.78 \%$. Unlike the impact of foreign forex supply and demand changes affecting the variables of exports and imports, changes in domestic forex supply and demand may cause changes in the import prices, where the effect of appreciation is greater than the effect of exchange rate depreciation. Meanwhile, other macroeconomic variables have the same effects. Another interesting finding is the influence of changes in foreign forex supply and demand that is greater than changes in domestic forex supply and demand. The value of such difference ranges between $3-4 \%$. This proves that the Indonesian forex market is vulnerable to the movement of domestic forex supply and demand.

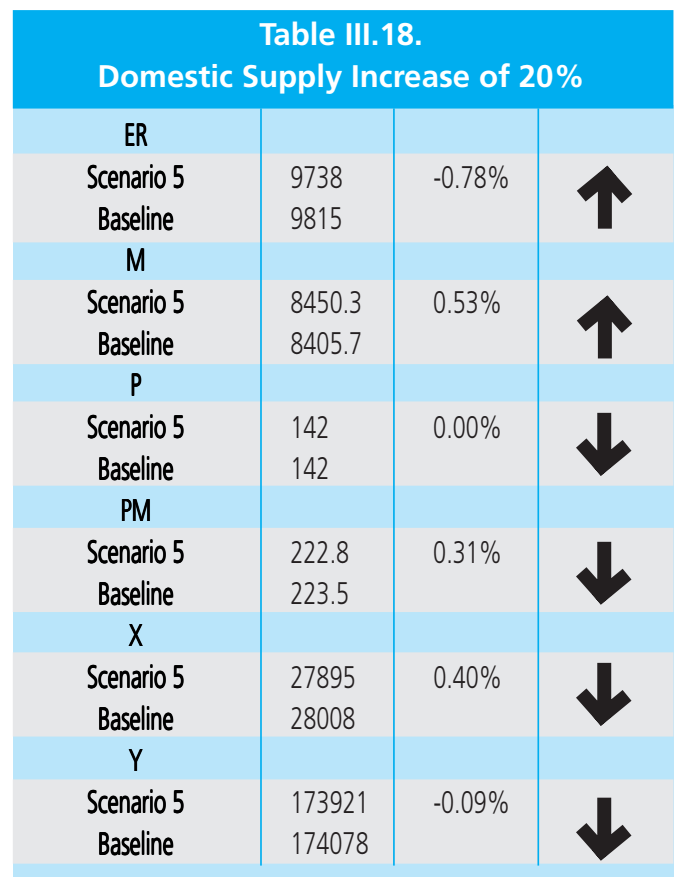

\begin{tabular}{|c|c|c|c|}
\hline \multicolumn{4}{|c|}{$\begin{array}{c}\text { Table III.19. } \\
\text { Domestic Demand Increase of } \mathbf{2 0 \%}\end{array}$} \\
\hline ER & & & \\
\hline $\begin{array}{c}\text { Scenario } 2 \\
\text { Baseline }\end{array}$ & $\begin{array}{l}9893 \\
9815\end{array}$ & $0.79 \%$ & \\
\hline$M$ & & & \\
\hline $\begin{array}{l}\text { Scenario } 2 \\
\text { Baseline }\end{array}$ & $\begin{array}{l}8361.5 \\
8405.7\end{array}$ & $0.53 \%$ & \\
\hline$P$ & & & \\
\hline $\begin{array}{l}\text { Scenario } 2 \\
\text { Baseline }\end{array}$ & $\begin{array}{l}142 \\
142\end{array}$ & $0.00 \%$ & \\
\hline PM & & & \\
\hline $\begin{array}{c}\text { Scenario } 2 \\
\text { Baseline }\end{array}$ & $\begin{array}{l}224.1 \\
223.5\end{array}$ & $0.27 \% 1$ & \\
\hline$x$ & & & \\
\hline $\begin{array}{c}\text { Scenario } 98152 \\
\text { Baseline }\end{array}$ & $\begin{array}{l}28121 \\
28008\end{array}$ & $0.40 \%$ & \\
\hline$Y$ & & & \\
\hline $\begin{array}{c}\text { Scenario } 2 \\
\text { Baseline }\end{array}$ & $\begin{array}{l}174236 \\
174078\end{array}$ & $0.09 \%$ & \\
\hline
\end{tabular}

4. The scenario of changes in domestic demand and forex supply is in the form of $20 \%$ decrease of forex supply and 20\% decrease of foreign currency demand. This scenario shows that although in net they have the same behaviour, depreciation caused by the supply decrease 
is greater than caused by the demand increase of forex. Therefore, to prevent a large depreciation is to prevent a large decline in forex supply. Similarly, the impact of forex demand decrease is greater than the forex supply increase in encouraging the appreciation of rupiah exchange rate.

\begin{tabular}{|c|c|c|c|c|c|c|}
\hline \multicolumn{4}{|c|}{$\begin{array}{l}\text { Table III. } 20 \text {. } \\
\text { Decline on Domestic Supply by } 20 \%\end{array}$} & \multicolumn{3}{|c|}{$\begin{array}{c}\text { Table III. } 21 . \\
\text { Decline on Domestic Demand by } 20 \%\end{array}$} \\
\hline ER & & & & & & \\
\hline Scenario 7 & 9494 & $0.85 \%$ & & & $-0.96 \%$ & \\
\hline Baseline & 9414 & & & & & \\
\hline M & & & & & & \\
\hline Scenario 7 & 8256.9 & $-0.42 \%$ & & & $0.65 \%$ & \\
\hline Baseline & 8292.1 & & & & & \\
\hline$P$ & & & & & & \\
\hline Scenario 7 & 141 & & & & 0.00 & \\
\hline Baseline & 141 & & & & & \\
\hline PM & & & & & & \\
\hline Scenario 7 & 230.1 & $0.35 \%$ & & & $0.40 \%$ & \\
\hline Baseline & 229.3 & & & & & \\
\hline$x$ & & & & & & \\
\hline Scenario 7 & 27921 & $0.43 \%$ & & & $-0.49 \%$ & \\
\hline & 27802 & & & & & \\
\hline$Y$ & & & & & & \\
\hline Scenario 7 & 172299 & $0.09 \%$ & & & $-0.11 \%$ & \\
\hline Baseline & 172145 & & & & & \\
\hline
\end{tabular}

\section{CONCLUSIONS AND RECOMMENDATIONS}

\section{V.1. Conclusions}

From this study, both from the market study segment and from the regression analysis segment, several conclusions may be drawn as follows:

1. Interaction between the forex supply and demand significantly affects the rupiah exchange rate, whereas the effect of foreign forex supply and demand is more dominant than the domestic one.

a. The more dominant influence of foreign forex demand and supply is confirmed by the analysis of forex market practice, which shows that foreign players are major players since their roles as a market mover and a counterweight of domestic demand and supply tend to be the excess demand.

b. However, the foreign forex demand and supply contributes asymmetric impacts to the exchange rate movement. In the event of net supply (capital inflows), while the amount may balance the domestic net demand, rupiah will be appreciated gradually. Conversely, 
in the event of rupiah net demand by the foreign party, it will be depreciated and the movement is more volatile.

c. Foreign players tend to be relatively very flexible - able to switch quickly from the net supply to the net demand, or vice versa - since the characteristic of forex transaction activities is trading to support short-term investments of foreign investors (portfolio investment). Meanwhile, the domestic players is divided in two parts, some of them support the business activities of real sectors (genuine transactions) and others are trading to gain profits.

2. Furthermore, the exchange rate affects the price developments and the economic output. Effects of exchange rate to prices in the first round effect - namely from the exchange rates to import prices - are quite strong and significant, but the second round effects to the customer prices is more limited. Effects of exchange rate to the exports and imports are only significant for the short term, mostly to the imports. Subsequently, exports and imports will affect the economic output. In addition, the asymmetric impact of exchange rate also occurs in the economy. The impact of exchange rate depreciation is greater than the impact of exchange rate appreciation, primarily the direct impact to the exports and imports. This difference causes the accumulation of different impacts on the economy.

3. Thus, the forex market faces several issues that potentially affect the exchange rate, namely:

a. Dependence of forex market and exchange rates against the forex supply of foreign players is high, and has been met by the forex supply in short-term characteristic.

b. The high trading activity --performed by almost all foreign players and some domestic players - indicates the high speculation to the rupiah exchange rate.

c. The development of forex market is less balanced where only the spot market is growing, while the forward and swap markets are stagnant. Undeveloped forward and swap markets become an inefficient hedging, though hedging is greatly needed in the market dominated by speculative activities. In addition, the need to perform forward or swap transactions, in turn, becomes a burden to the spot market.

Above problems make the forex market and exchange rates are highly vulnerable to the capital reversal and correction of exchange rate when the motion is due to speculative transactions are not in line with economic fundamentals.

\section{V.2. Policy Recommendations}

The problems occurring in the forex market have a potential to make an unstable exchange rate and further affect the inflation rate, exports and imports, and output. To minimize the negative impacts, some measures of policies may be carried out as follows: 


\section{Balancing Forex Supply and Demand}

1. The balancing efforts must begin with the monitoring demand and supply developments in the forex market, including significant player activities, to anticipate the occurrence of exchange rate imbalance and volatility. In the event of a significant imbalance, the balancing efforts are required. The supply of forex demand should be conducted as follows:

a. increasing the domestic forex supply or decreasing the domestic forex demand.

Stages to reduce forex demand are relatively limited since the Bank of Indonesia does not have the authority to restrict them. The only thing that $\mathrm{BI}$ can do is not intervening in order to absorb forex from the market, and by coordinating with the Government to advise that the purchase of forex by SOE should be restricted or the timing should be set, for example, when a large amount of capital inflows occur. In contrast, BI can make some efforts to increase the forex supply by selling forex interventions. BI needs to continue the selling forex interventions that have been conducted regularly by still taking into account the level of need (namely to meet the genuine demand) and the implementation time (namely outflows occur and rupiah is depressed).

b. attracting more foreign forex supply, particularly the more permanent one (such as FDI, export results that are placed abroad, worker remittances, foreign tourist extradition, and so forth), or avoiding the capital reversal.

To prevent a reversal capital, there should be some efforts to maintain the condition or portfolio investment climate in Indonesia to keep it attractive for foreign investors. Stages may be done cover: maintaining the rupiah stability, maintaining the prudent and transparent macroeconomic policies and coordinating with the government to encourage the issuance of new investment instruments (adding alternative investment outlets). Meanwhile, to attract more forex supply through FDI, worker remittances and foreign tourists, it is necessary together with the government to create a conducive investment climate, in order to attract more Indonesian workers who live abroad (especially those trained and educated) and to increase the attractiveness of tourism in Indonesia. .

To Handle the High Forex Trading and To Promote the Hedging Market Growth

2. Amid the high trading activities that tend to be speculative, some efforts to protect the genuine demand/supply are required, particularly the scheduled one, such as import payments, export revenues and foreign debt payments, by developing the hedging markets (forward and swap markets). Stages may be taken by BI consist of: activating forex intervention more through forward and swap transactions, as well as making the existing re-swap hedging facilities be more attractive to banks. 


\section{REFERENCES}

Evans, Martin D.D., dan Richard K. Lyons. 2005. "Understanding Order Flow". Working Paper \#11748, NBER, Massachusetts.

Husman, Jardine A. 2005." "Estimasi Nilai Tukar Paska Krisis: Pendekatan Model Komposit". The Bank of Indonesia Working Paper 07/2005. Jakarta.

Kurniati, Yati, Tri Yanuarti dan Yanfitri. 2008. "Dampak Nilai Tukar terhadap Harga Impor dan Inflasi Inti". The Bank of Indonesia, Catatan Riset 10/6/DKM/BRE/CR.

Kurniati, Yati, 2007. "Exchange Rate Pass-Through In Indonesia"

Lyons, Richard K. 2001. "The Microstructure Approach to Exchange Rates". MIT Press, Cambridge, Massachusetts.

Rime, Dagfinn, Lucio Sarno, dan Elvira Sojli. 2007. "Exchange Rate Forecasting, Order Flow, and Macroeconomic Information". Oslo ANO 2007/2. 